\title{
The Effect of Different Parameters on the Development of Compressive Strength of Oil Palm Shell Geopolymer Concrete
}

\author{
Ramin Hosseini Kupaei, U. Johnson Alengaram, and Mohd Zamin Jumaat \\ Department of Civil Engineering, Faculty of Engineering, University of Malaya, 50603 Kuala Lumpur, Malaysia \\ Correspondence should be addressed to U. Johnson Alengaram; ujohnrose@yahoo.com
}

Received 1 July 2014; Accepted 27 August 2014; Published 28 October 2014

Academic Editor: Fabrizio Scala

Copyright ( 2014 Ramin Hosseini Kupaei et al. This is an open access article distributed under the Creative Commons Attribution License, which permits unrestricted use, distribution, and reproduction in any medium, provided the original work is properly cited.

\begin{abstract}
This paper presents the experimental results of an on-going research project on geopolymer lightweight concrete using two locally available waste materials-low calcium fly ash (FA) and oil palm shell (OPS) - as the binder and lightweight coarse aggregate, respectively. OPS was pretreated with three different alkaline solutions of sodium hydroxide $(\mathrm{NaOH})$, potassium hydroxide, and sodium silicate as well as polyvinyl alcohol (PVA) for 30 days; afterwards, oil palm shell geopolymer lightweight concrete (OPSGPC) was cast by using both pretreated and untreated OPSs. The effect of these solutions on the water absorption of OPS, and the development of compressive strength in different curing conditions of OPSGPC produced by pretreated OPS were investigated; subsequently the influence of $\mathrm{NaOH}$ concentration, alkaline solution to FA ratio (A/FA), and different curing regimes on the compressive strength and density of OPSGPC produced by untreated OPS was inspected. The 24-hour water absorption value for OPS pretreated with $20 \%$ and $50 \%$ PVA solution was about $4 \%$ compared to $23 \%$ for untreated OPS. OPSGPC produced from OPS treated with 50\% PVA solution produced the highest compressive strength of about $30 \mathrm{MPa}$ in ambient cured condition. The pretreatment with alkaline solution did not have a significant positive effect on the water absorption of OPS aggregate and the compressive strength of OPSGPC. The result revealed that a maximum compressive strength of $32 \mathrm{MPa}$ could be obtained at a temperature of $65^{\circ} \mathrm{C}$ and curing period of 4 days. This investigation also found that an A/FA ratio of 0.45 has the optimum amount of alkaline liquid and it resulted in the highest level of compressive strength.
\end{abstract}

\section{Introduction}

The worldwide consumption of cement has risen to around 2.6 billion and the use of virgin materials in the production of cement has had negative impact on the environment [1]. Further, large amount of energy is consumed in the production of cement and as a result, cement industry has become one of the largest contributors of carbon dioxide $\left(\mathrm{CO}_{2}\right)$. Research works on minimizing the use of cement through waste materials such as fly ash (FA) and ground granulated blast furnace slag (GGBS) produced positive outcome. Alkaline-activated binders are produced by the activation of different natural materials and industrial by-products such as FA, metakaolin, GGBS, kaolinitic clays, rice husk ash (RHA), and red mud are being used in the development of cementless concrete [2].

Many researchers focussed their attention on the use of FA as an environmental friendly material to replace cement in concrete. FA is a kind of by-product derived from the combustion of pulverized coal and collected by mechanical and electrostatic separators from the fuel gases of power plants [3]. FA is the residue of power plant furnaces and is formed from mineral substances of particles and mainly alumino-silicate-based ceramic spheres with a lesser number of iron-rich spheres [4]. The origin of the coal and how it was combusted are factors that will determine the final properties of coal FA [5]. According to the ASTM C618, FA can be classified as being either Class F or Class C; fly ash with Class C contains higher levels of calcium [6]. Fly ash with lower levels of calcium is preferred for geopolymers because high amount of calcium can impact the process of polymerization and change the microstructure of the final geopolymer [7].

Recently geopolymer concrete brought the attention of many researchers worldwide. The use of industrial byproducts such as FA, GGBS, RHA, metakaolin, silica fume, 
limestone powder, and shale oil ash in the development of geopolymer mortar and the concrete is becoming more common [8]. In order to achieve a suitable chemical composition in the development of geopolymers, the preferred method is to blend FA with another high silica material [911]. In previous studies, researchers made use of metakaolinite to obtain geopolymers by reaction with alkaline metal $(\mathrm{Na}$ or K) silicate [12-14]. For the calculation of different types of geopolymer composites, it is important that geopolymer skeleton network is formed through different kinds of materials (sand, mica, etc.). This property opens the possibility to appropriate the quality of geopolymer composite to the substitute material [15]. The production of geopolymers takes place by polycondensation and can start from a variety of raw materials. Geopolymeric materials are attractive because of excellent mechanical properties and durability [16]. Furthermore, due to much lower $\mathrm{Ca}$ content, geopolymerbased materials are much more resistant to acid attack than Portland cement based ones [17]. The applications of geopolymer-based materials include a wide range of products such as new ceramics, cements, matrices for hazardous waste stabilization, fire-resistant materials, asbestos-free materials, and high-tech materials [18]. Recent literatures stated that geopolymer mortar can be used as a repair material since the bonding between geopolymer mortar and substrate materials was high enough compared to commercial repair materials [19].

Olivia and Nikraz [20] investigated the effects of aggregate content, alkaline solution to $\mathrm{FA}$ ratio (A/FA), sodium silicate to sodium hydroxide ratio, and curing method on FA based geopolymer concrete. They reported that geopolymer concrete can be produced with a 28-day compressive strength of $55 \mathrm{MPa}$. The specimens had higher tensile and flexural strength, produced less expansion and drying shrinkage, and showed 14.9-28.8\% lower modulus of elasticity than the OPC control mix. Nazari et al. [21] considered the factors that affect the compressive strength and proposed a suitable procedure for producing OPC geopolymer. In the previous works by Riahi et al. [22, 23], the main factors affecting the compressive strength of ash based geopolymers include the particle size of the utilized ash, curing temperature, curing time, and $\mathrm{NaOH}$ concentration. The binder in geopolymer concrete is different from that in OPC concrete; the effect of the interaction between the aggregates and the geopolymer binder was investigated by Sarker et al. [24]. Even though aggregate constitutes major volume in geopolymer concrete, only limited study related to this parameter has been reported.

The use of waste materials by construction industry for sustainable development is gaining worldwide attention and a lot of waste materials are being used or recycled. The use of recycled aggregates in pervious geopolymer concrete (PGC) was studied by Sata et al. [25]. They reported that both the concrete aggregate and crushed clay bricks from the demolished structural concrete member can be used as recycled coarse aggregates for making PGC with acceptable properties. Joseph and Mathew [26] conducted a study on the influence of aggregate content on the engineering properties of geopolymer concrete. Recently, there was an attempt by Kupaei et al. [27] to utilize local industrial waste known as oil palm shell (OPS) as coarse aggregate in oil palm shell geopolymer concrete (OPSGPC). They reported that mix design for the geopolymer concrete produced with OPS differs widely from the procedure used for mix proportioning of concrete using conventional lightweight and normal weight aggregates.

In Malaysia and few other South East Asian countries, the production of palm oil results in a lot of industrial waste products, including OPS. The annual production of OPS is approximately 4.56 million tonnes and these are dumped in the factory yards or used as fuel to operate generators. Many researchers in South Asia and African countries have been researching to replace the conventional crushed granite aggregate with OPS as lightweight aggregate [28-32]. The mix design for OPS concrete (OPSC) has resulted in concrete with sufficient strength, as specified for structural lightweight concrete, and has given satisfactory workability with superplasticizer [30]. Alengaram et al. [29] reported an $E$ value in the range of 5.5-11 GPa for the OPSC. Further, the aggregate interlock property of OPS enabled higher shear strength of OPSC than the conventional concrete made with crushed granite aggregate [31]. Alengaram et al. [33] reported that the thermal conductivity of $0.45 \mathrm{~W} / \mathrm{m}^{\circ} \mathrm{K}$ (Watts/metre Kelvin) for OPSC lies within the range of 0.05 and $0.69 \mathrm{~W} / \mathrm{m}^{\circ} \mathrm{K}$ of other lightweight aggregate concrete. Shafigh et al. [34] presented a new method using crushed OPS to produce OPSC and reported 28- and 56-day compressive strength of about 53 and $56 \mathrm{MPa}$, respectively. Though many researchers focussed their attention on the mechanical, functional and structural aspects of OPSC, there is hardly any evidence on the effect of chemicals on OPS; only Mannan et al. [35] reported the effect of different chemicals on the OPS and found that polyvinyl alcohol (PVA) had a positive effect due to an increase in the compressive strength of about $41 \%$ compared to OPSC with untreated OPS in the OPSC. Since OPS is being used in geopolymer concrete as coarse aggregate [27], the effect of alkaline activators on OPS is vital.

The mechanical properties of concrete are strongly affected by the bond between cement paste and aggregate at the interfacial transition zone (ITZ) [36]. There are good correlations between microstructure characteristics of ITZ and compressive strength [37]. Brough and Atkinson [36] studied the ITZ in alkali-activated slag cement paste. They reported no enhanced interfacial porosity due to filling up the ITZ by the hydration products in sodium silicateactivated slag cement mortars. Demie et al. [37] conducted an experimental study on the correlations between compressive strength development and ITZ in self-compacting geopolymer concrete. They reported that improved performance of concrete was found when the compressive strength increased through formation of dense ITZ between the aggregate and binder matrix at higher superplasticizers (SP) dosage.

Geopolymers require rather longer heat curing times to develop their strength. A 53\% increase in strength has been recorded after the geopolymer was cured using heat [38]. Because water is a fundamental component of alkaline activation reactions, the geopolymer curing process becomes more important [39]. The presence of humidity during the curing process can affect the structural and mechanical 
TABle 1: Chemical composition of used fly ash and ordinary Portland cement (\%).

\begin{tabular}{lcccccccccccccccc}
\hline Content & $\mathrm{SiO}_{2}$ & $\mathrm{Al}_{2} \mathrm{O}_{3}$ & $\mathrm{Fe}_{2} \mathrm{O}_{3}$ & $\mathrm{CaO}$ & $\mathrm{MgO}$ & $\mathrm{SO}_{3}$ & $\mathrm{~K}_{2} \mathrm{O}$ & $\mathrm{Na}_{2} \mathrm{O}$ & $\mathrm{MnO}$ & $\mathrm{TiO}_{2}$ & $\mathrm{P}_{2} \mathrm{O}_{5}$ & $\mathrm{Cr}_{2} \mathrm{O}_{3}$ & $\mathrm{Sr}$ & $\mathrm{Zn}$ & $\mathrm{LOI}$ \\
\hline FA & 57.6 & 28.9 & 5.79 & 0.18 & 0.91 & 0.23 & 0.86 & 0.38 & 0.035 & 1.843 & 0.463 & 0.016 & 0.101 & 0.022 & 3.63 \\
$\mathrm{OPC}$ & 19.03 & 4.6 & 3.05 & 63.02 & 2.64 & 2.58 & 1.03 & 0.26 & 0.127 & 0.250 & 0.030 & 0.003 & 0.069 & 0.009 & 2.58 \\
\hline
\end{tabular}

properties of alkaline activated FA pastes, mortars, and concretes [40]. Typically, 70\% of the compressive strength is developed during the first 12 hours of the curing process [41]. To reach its optimum strength, geopolymer concrete should be cured at temperatures ranging from $40^{\circ} \mathrm{C}$ to $80^{\circ} \mathrm{C}$ for at least 6 hours [42, 43], although Škvára et al. [44] have claimed that compressive strength can continue to grow for several years. Temuujin et al. [45] suggested that the curing temperatures used during the first 4 to 48 hours are critical for the manufacture of geopolymers. Palomo et al. [43] found that reactions in FA based geopolymers are accelerated by curing temperatures. Conversely, Hardjito et al. [46] claimed that higher curing temperatures do not guarantee higher compressive strength.

Elevated curing temperatures give geopolymers ceramic like properties and additional benefits [47]. The strength of geopolymers increases after exposure to elevated temperatures [48] and this means that its resistance to fire should be better compared to concrete that uses Portland cement, which loses a substantial amount of its strength after being exposed to temperatures greater than $800^{\circ} \mathrm{C}$ [38]. Kani et al. [49] examined hydrothermal curing at elevated temperatures; they found that efflorescence was reduced when the components were not rich in aluminum.

This investigation focuses on the effect of different types of alkaline solutions on the OPS. The OPS was soaked in alkaline activators of $\mathrm{NaOH}$, potassium hydroxide $(\mathrm{KOH})$, and sodium silicate of $14 \mathrm{M}$ and the effect of these activators on the water absorption and compressive strength in two curing conditions of oven-cured and ambient cured specimens was investigated. Further, the effect of PVA on the OPS was also investigated and reported. The use of organic aggregate such as OPS in geopolymer concretes makes different characteristics and behavior for them, compared to the use of normal aggregates, and there is no research on the effect of heat curing on the compressive strength of OPSGPC. With these considerations, further objectives of the present study were (i) to obtain the effect of different ratios of alkaline activator solution-to-FA, (ii) to investigate the effect of different molarities of alkaline activators, and (iii) to determine the effect of curing period $(1,1.5,2,3,4$, 5,8 , and 10 days) and temperature (room temperature of $30,50,65,80,95$, and $110^{\circ} \mathrm{C}$ ) on the compressive strength of OPSGPC. The OPSGPC was prepared using class F-FA as binder, pretreated and untreated OPS as coarse aggregate, and suitable alkaline activators.

\section{Materials}

2.1. Fly Ash. FA was used as the main binder in this investigation and its chemical composition was determined by X-ray fluorescence (XRF) analysis and expressed as a percentage of

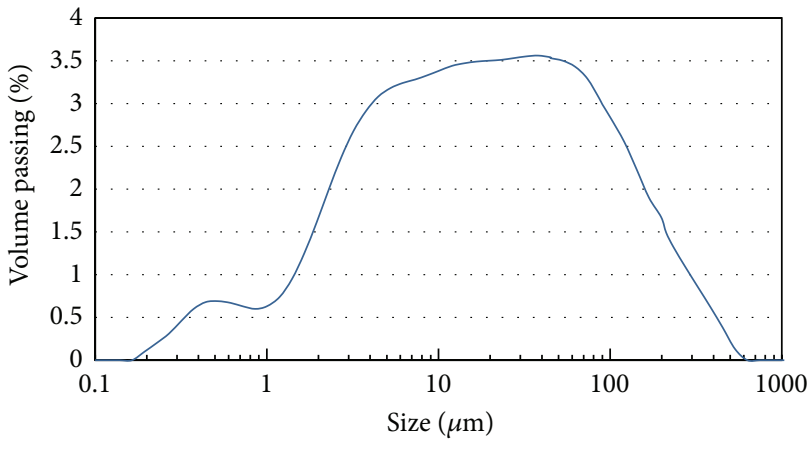

FIgure 1: Particle size distribution of fly ash.

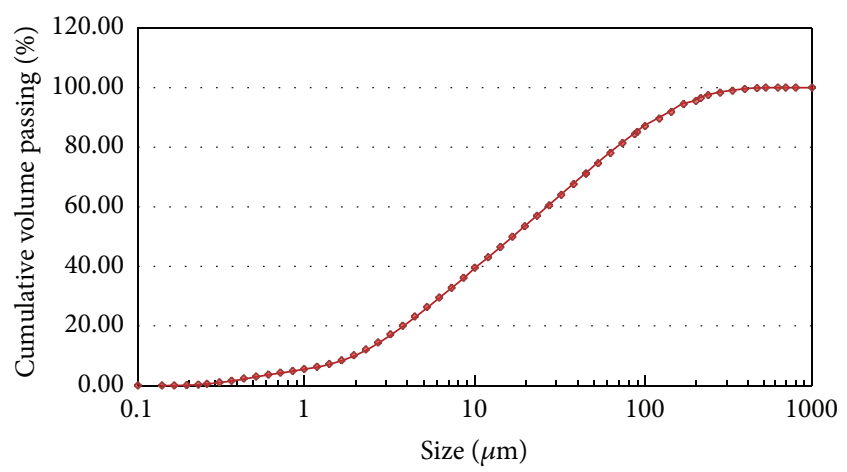

FIGURE 2: Cumulative particle size distribution of fly ash.

the overall mass of the constituent oxides as shown in Table 1. The FA used in this study was obtained from Lafarge Malayan Cement Bhd, Malaysia. As shown in Table 1, the FA used in this study had a very low percentage of carbon, as indicated by the low loss on ignition (LOI) values. The Si-to-Al ratio was about 2 , and the calcium oxide content was also very low. The iron oxide $\left(\mathrm{Fe}_{2} \mathrm{O}_{3}\right)$ content was relatively low. As a result, the colour of the FA was darker than ordinary Portland cement (OPC), which contains less iron oxide.

The results of a particle size analysis of the FA revealed that $81.6 \%$ of the particles were smaller than $62 \mu \mathrm{m}$ and fit with the parameters shown in Figure 1. The cumulative particle size distribution of the FA is given in Figure 2.

The spherical particle shape results of FESEM analysis of the FA are shown in Figure 3.

2.2. Fine Aggregate. The commonly used fine aggregate in Malaysia is mining sand. The 24-hour water absorption of the fine aggregate was found as $0.96 \%$ and the only size between $5.0 \mathrm{~mm}$ and $300 \mu \mathrm{m}$ used in this investigation. The specific gravity and fineness modulus of used fine aggregates were 2.68 and 2.73 , respectively. 


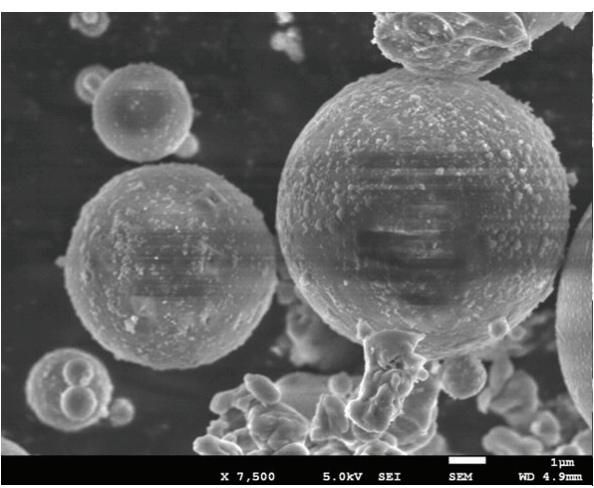

(a)

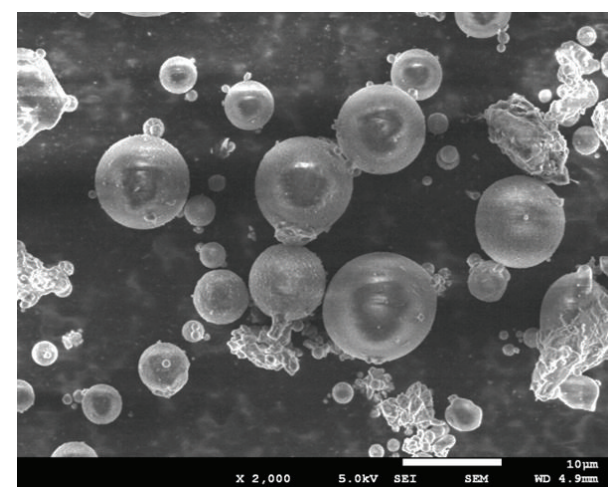

(b)

FIGURE 3: FESEM photography of fly ash particles.

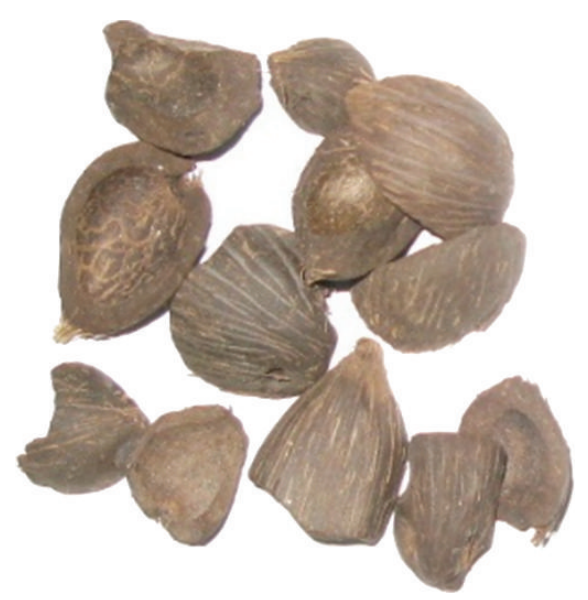

(a)

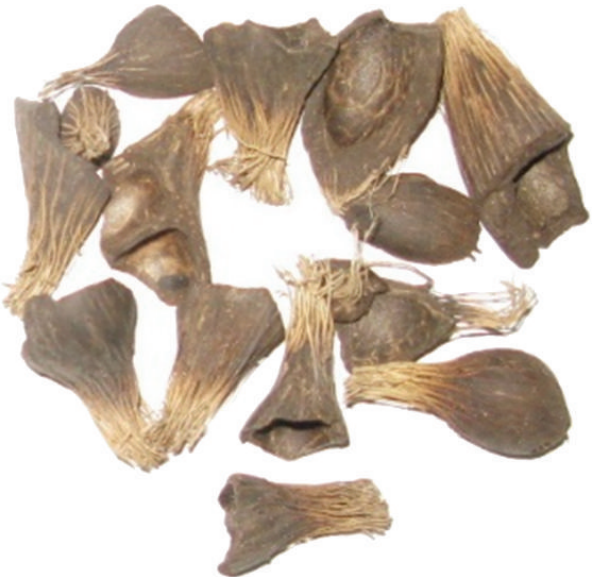

(b)

FIGURE 4: (a) Old OPS without fibres. (b) Fresh OPS with fibres.

2.3. Coarse Aggregate. The fresh OPS includes fibres as shown in Figure 4(b) which absorb the paste water and decrease the workability and also reduce the contact area between the OPS surface and the mortar, which causes a weak interfacial transition zone [34], so the old disposed OPS in the vicinity of the palm oil factory was used for this investigation. The old OPS obtained from the local palm oil factory had dirt and the size measured up to a maximum of $14 \mathrm{~mm}$. The OPS was washed by detergent to remove dirt, oil, and lump of clay and then dried before crushing into different sizes as shown in Figure 5. The OPS sizes bigger than $1.18 \mathrm{~mm}$ were used as coarse aggregate in this investigation. The physical properties and the grading of OPS are shown in Tables 2 and 3 , respectively.

2.4. Water and Superplasticizer. Potable tap water from the pipeline in the lab was kept in the bucket for 24 hours to release chlorine before it was used. In this study, each mixture contained a naphthalene sulphonated superplasticizer to improve the workability of the concrete mix. Criado et al. [50] discussed the importance of using SP in FA based geopolymer concrete. The total water included the water added to

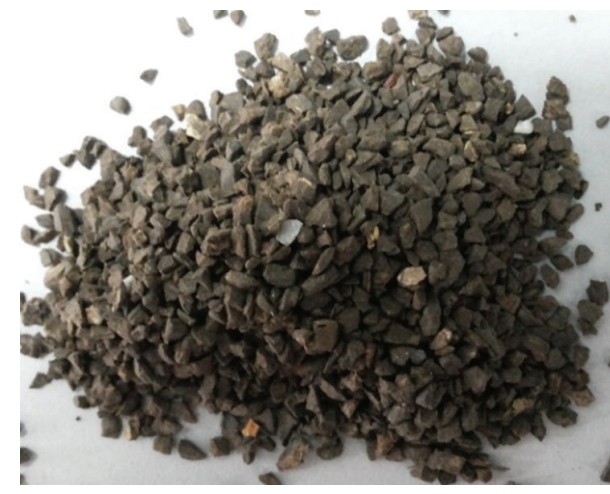

FIGURE 5: Crushed OPS aggregates with size of $1.18 \mathrm{~mm}$ to $5 \mathrm{~mm}$.

the solution and to the concrete. Therefore, the term waterto-FA (W/FA) ratio includes the total water used in each mixture.

2.5. Alkaline Activators. The commonly used activators in geopolymer concretes are a combination of $\mathrm{NaOH}$ or $\mathrm{KOH}$ and sodium silicate $\left(\mathrm{Na}_{2} \mathrm{SiO}_{3}\right)$ or potassium silicate. 
TABLE 2: Physical properties of OPS aggregate.

\begin{tabular}{lc}
\hline Physical property & OPS \\
\hline Specific gravity (saturated surface dry) & 1.18 \\
Bulk density (compacted) $\left(\mathrm{kg} / \mathrm{m}^{3}\right)$ & 596 \\
Fineness modulus & 5.53 \\
Water absorption $(24 \mathrm{~h})(\%)$ & 22.78 \\
\hline
\end{tabular}

TABLE 3: Grading of OPS aggregates.

\begin{tabular}{lc}
\hline Sieve size $(\mathrm{mm})$ & Percentage retained $(\%)$ \\
\hline 4.75 & 10.2 \\
3.54 & 33.5 \\
2.36 & 37.2 \\
1.18 & 19.1 \\
\hline Total & 100 \\
\hline
\end{tabular}

The most effective mixtures contain $\mathrm{NaOH}$ and $\mathrm{Na}_{2} \mathrm{SiO}_{3}$ because partially dissolved and polymerized silicon reacts well with other components in the mixture to improve the mortar [51]. Xu and van Deventer [52] claimed that $\mathrm{NaOH}$ and $\mathrm{Na}_{2} \mathrm{SiO}_{3}$ improved the process of geopolymerization. In the present study, a combination of $\mathrm{NaOH}$ and $\mathrm{Na}_{2} \mathrm{SiO}_{3}$ solution with molarities that ranged from of 8 to $16 \mathrm{M}$ was chosen as the alkaline activator [27].

The $\mathrm{NaOH}$ and $\mathrm{KOH}$ solution was prepared by dissolving the pellets in water. The mass of $\mathrm{NaOH}$ and $\mathrm{KOH}$ solids in a solution varies depending on the concentration of the solution expressed in terms of molar, $\mathrm{M}$. For instance, $\mathrm{NaOH}$ solution with a concentration of $14 \mathrm{M}$ consists of $14 \times 40=$ 560 grams of $\mathrm{NaOH}$ solids per litre of the solution, where 40 is the molecular weight of $\mathrm{NaOH}$. The mass of $\mathrm{NaOH}$ solids was calculated as 431 grams per $\mathrm{kg}$ of $\mathrm{NaOH}$ solution for $14 \mathrm{M}$ concentration. The similar calculation was done for the $\mathrm{KOH}$ solution. $\mathrm{KOH}$ solution with a concentration of $14 \mathrm{M}$ consists of $14 \times 56.12=785.68$ grams of $\mathrm{KOH}$ solids per litre of the solution, where 56.12 is the molecular weight of $\mathrm{KOH}$. The mass of $\mathrm{KOH}$ solids was calculated as 561 grams per $\mathrm{kg}$ of $\mathrm{KOH}$ solution for $14 \mathrm{M}$ concentration. The composition of the $\mathrm{Na}_{2} \mathrm{SiO}_{3}$ solution used was $\mathrm{Na}_{2} \mathrm{O}=12 \%, \mathrm{SiO}_{2}=30 \%$, and water $58 \%$ by mass. The other characteristics of the $\mathrm{Na}_{2} \mathrm{SiO}_{3}$ solution were specific gravity and viscosity at $20^{\circ} \mathrm{C}$ of $1.53 \mathrm{~g} / \mathrm{cc}$ and $400 \mathrm{cP}$, respectively. The ratio of $\mathrm{Na}_{2} \mathrm{SiO}_{3}$ to $\mathrm{NaOH}$ solution was kept constant at 2.5 for all the OPSGPC specimens. The ratio of activator solution-to-fly ash (A/FA), by mass, was changed between 0.2 and 0.55 for different mixes. The total water includes the water added in solution and the water added to concrete. Therefore, the term water to FA (W/FA) ratio implies the total water in the mixes. The combination of sodium silicate and $\mathrm{NaOH}$ used as alkaline activator solutions in OPSGPC was kept at room temperature for at least 24 hours before mixing it in the concrete.

\section{Experiment Programme}

Initially, the effect of $\mathrm{NaOH}, \mathrm{KOH}$, sodium silicate, and also PVA on the water absorption of OPS, development of compressive strength, and curing condition of OPSGPC produced by pretreated OPS was studied in this investigation. Next, the effect of the molarity of the alkaline activators on the compressive strength of the OPSGPC produced by untreated OPS was investigated. Then, the optimum amounts of alkaline activator-to-FA (A/FA) ratio were determined. Finally, the optimum curing temperature and curing period for the OPSGPC produced by untreated OPS was investigated. The mixture used in this study was $1 / 0.74 / 0.66$ (FA/Sand/OPS) by weight, with FA content of $480 \mathrm{~kg} / \mathrm{m}^{3}, 355.2 \mathrm{~kg} / \mathrm{m}^{3}$ of sand, and $316.8 \mathrm{~kg} / \mathrm{m}^{3}$ of OPS. The water and SP contents were $66 \mathrm{~kg} / \mathrm{m}^{3}$ and $9.5 \mathrm{~L} / \mathrm{m}^{3}$, respectively, based on our previous work [27].

3.1. Pretreatment and Preparation of OPS Aggregates Using Different Chemicals. The first objective of the work was to study the effect of four different chemicals such as $\mathrm{NaOH}$, $\mathrm{KOH}, \mathrm{Na}_{2} \mathrm{SiO}_{3}$, and PVA on OPS. Since OPS used in the OPSGPC has direct contact with the alkaline activators, it is imperative to know the effect of the activators on OPS. PVA solution was prepared by dissolving 100 grams of powder form of PVA in 900 grams of water. It should be noted that liquid form of the $\mathrm{Na}_{2} \mathrm{SiO}_{3}$ solution was used in this investigation. The $\mathrm{NaOH}$ solution with a concentration of $14 \mathrm{M}$ was prepared by dissolving 431 grams of $\mathrm{NaOH}$ solids into 569 grams of water. Likewise, $\mathrm{KOH}$ solution with a concentration of $14 \mathrm{M}$ consists of 561 grams of $\mathrm{KOH}$ solids and 439 grams water per $\mathrm{kg}$ of the solution was prepared. The OPS was soaked in these chemicals with different percentages for 30 days and then taken out to get dried and to be used in OPSGPC as coarse aggregate. In order to obtain $5 \%, 20 \%$, and $50 \%$ pretreatment solutions per $\mathrm{kg}, 50,200$, and 500 grams of each of the above mentioned solutions were added to 950 , 800 , and 500 grams of water, respectively, and used in the pretreatment of OPS. Figure 6 shows the soaked OPS in four different chemicals. The water absorption of these pretreated OPS was measured and reported. Table 4 shows the different concentration of the solutions and their designations.

3.2. Specimen Preparation for the Effect of Different Pretreatment. The properties investigated in this part of study include the effect of different pretreatment of OPS on the development of compressive strength of OPSGPC produced by pretreated OPS. All the dry materials were mixed in a pan mixer for three minutes and then the alkaline activator solution was added. The wet mixing continued for another four minutes [27]. The concrete was then cast in the $50 \mathrm{~mm}$ cube moulds and poured in three phases and each layer was compacted uniformly. For each mix proportion, 24 specimens were cast. Immediately after casting, the specimens along with the moulds were concealed using plastic and then kept in respective curing conditions to prevent evaporation. The average value of three specimens is reported as the compressive strength.

3.3. Specimen Preparation for the Effect of Curing Method. The properties explored in this part of investigation were the effect of two different curing methods on the development of compressive strength of OPSGPC produced by pretreated OPS. 
TABLE 4: Type of chemicals used for pretreatment of OPS aggregates.

\begin{tabular}{|c|c|c|c|c|c|}
\hline \multirow{2}{*}{ SI } & \multirow{2}{*}{ Pretreatment methods } & \multicolumn{3}{|c|}{ Mass proportion in kg of solution (gr) } & \multirow{2}{*}{ Designation } \\
\hline & & Solid & Liquid & Water & \\
\hline 1 & $\begin{array}{l}\text { Pretreated in } 5 \% \text { of } 14 \mathrm{M} \text { sodium } \\
\text { hydroxide solution }\end{array}$ & 21.6 & - & 978.4 & $\mathrm{~A} 1$ \\
\hline 2 & $\begin{array}{l}\text { Pretreated in } 20 \% \text { of } 14 \mathrm{M} \text { sodium } \\
\text { hydroxide solution }\end{array}$ & 86.2 & - & 913.8 & $\mathrm{~A} 2$ \\
\hline 3 & $\begin{array}{l}\text { Pretreated in } 50 \% \text { of } 14 \mathrm{M} \text { sodium } \\
\text { hydroxide solution }\end{array}$ & 215.5 & - & 784.5 & A3 \\
\hline 4 & $\begin{array}{l}\text { Pretreated in } 5 \% \text { of } 14 \mathrm{M} \text { potassium } \\
\text { hydroxide solution }\end{array}$ & 28.1 & - & 971.9 & $\mathrm{~B} 1$ \\
\hline 5 & $\begin{array}{l}\text { Pretreated in } 20 \% \text { of } 14 \mathrm{M} \text { potassium } \\
\text { hydroxide solution }\end{array}$ & 112.2 & - & 887.8 & $\mathrm{~B} 2$ \\
\hline 6 & $\begin{array}{l}\text { Pretreated in } 50 \% \text { of } 14 \mathrm{M} \text { potassium } \\
\text { hydroxide solution }\end{array}$ & 280.5 & - & 719.5 & B3 \\
\hline 7 & $\begin{array}{l}\text { Pretreated in } 5 \% \text { of sodium silicate } \\
\text { solution }\end{array}$ & - & 50.0 & 950.0 & $\mathrm{C} 1$ \\
\hline 8 & $\begin{array}{l}\text { Pretreated in } 20 \% \text { of sodium silicate } \\
\text { solution }\end{array}$ & - & 200.0 & 800.0 & $\mathrm{C} 2$ \\
\hline 9 & $\begin{array}{l}\text { Pretreated in } 50 \% \text { of sodium silicate } \\
\text { solution }\end{array}$ & - & 500.0 & 500.0 & $\mathrm{C} 3$ \\
\hline 10 & Pretreated in $5 \%$ of PVA solution & 5.0 & - & 995.0 & D1 \\
\hline 11 & Pretreated in $20 \%$ of PVA solution & 20.0 & - & 980.0 & D2 \\
\hline 12 & Pretreated in $50 \%$ of PVA solution & 50.0 & - & 950.0 & D3 \\
\hline 13 & Without any pretreatment & - & - & - & $\mathrm{E}$ \\
\hline
\end{tabular}

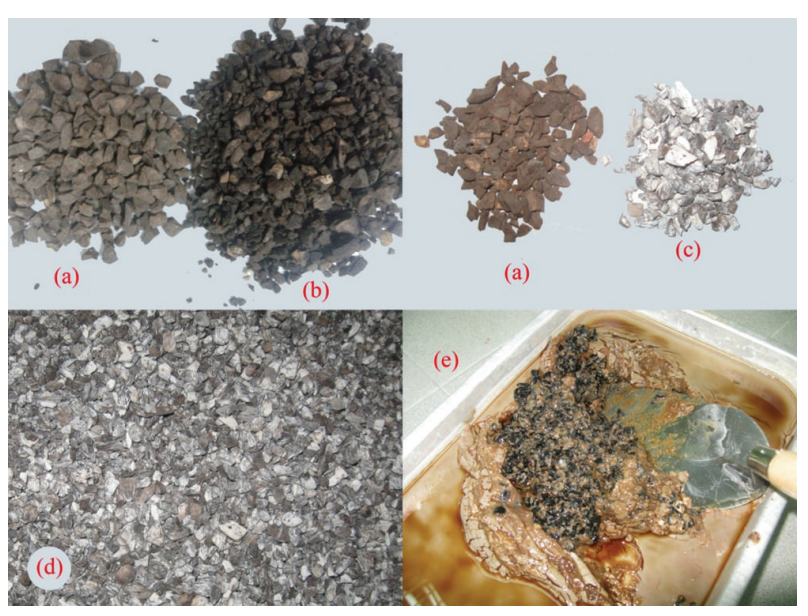

FIGURE 6: OPS aggregates soaked in (a) water, (b) PVA, (c) $\mathrm{NaOH}$, (d) $\mathrm{KOH}$, and (e) sodium silicate solutions.

Two curing methods, namely ambient cured and oven-cured were selected to investigate the development of compressive strength. The oven-cured specimens were cured in an oven at $65^{\circ} \mathrm{C}$ for 48 hours and were taken out and left in room temperature and humidity of 28 to $31^{\circ} \mathrm{C}$ and $60 \%$, respectively, till the day of testing. The ambient-cured specimens were kept in the room condition with temperature and humidity as stated above till the day of testing. This procedure was adopted based on the method suggested by Hardjito et al. [53].
3.4. Preparation of Specimens for Different Molarities. A total of 5 mixtures with molarities ranging from $8 \mathrm{M}$ to $16 \mathrm{M}$ were created to study how different concentrations of $\mathrm{NaOH}$ influenced the compressive strength and density of an OPSGPC produced by untreated OPS. Each OPSGPC mixture had an alkaline activator-to-FA (A/FA) ratio of 0.35 , water, an OPS with maximum nominal size of $5 \mathrm{~mm}$, a fine aggregate, and FA. These factors were kept constant. The samples were cured in an oven for 48 hours at $65^{\circ} \mathrm{C}$ [27]. After the specimens were taken out of the oven, they were left at ambient condition of 28 to $31^{\circ} \mathrm{C}$ temperature and $60 \%$ humidity till test day.

3.5. Preparation of Specimens for Different A/AF Ratios. A total of eight mixtures were prepared with different ratios of A/FA $(0.2,0.25,0.3,0.35,0.4,0.45,0.5$, and 0.55 by mass), to investigate the optimum ratio for use in OPSGPCs produced by untreated OPS. All dry materials were mixed in a pan mixer for four minutes before adding the alkaline activator solution. After the activator was added, the resulting compound was mixed for another five minutes. The concrete was cast in $50 \mathrm{~mm}$ cube molds and poured in two layers and compacted with steel rods, as described in ASTM C109. The water-to-FA (W/FA) ratio was fixed at 0.37 for each mixture with $\mathrm{FA} /$ sand/OPS ratio of $1 / 0.74 / 0.66$; the quantity of $\mathrm{FA}$, additional water, and $\mathrm{SP}$ were $480 \mathrm{~kg} / \mathrm{m}^{3}$, $66 \mathrm{~kg} / \mathrm{m}^{3}$, and $9.5 \mathrm{~L} / \mathrm{m}^{3}$, respectively. The molarity of the alkaline activator was $14 \mathrm{M}$. For each mixture, 6 specimens were cast. Water evaporation was prevented after casting by immediately sealing top of the molds with a thin, plastic layer. 


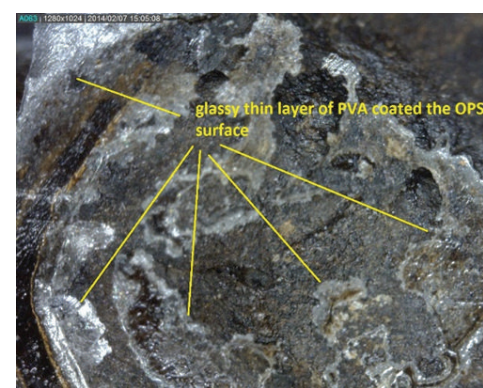

(a)

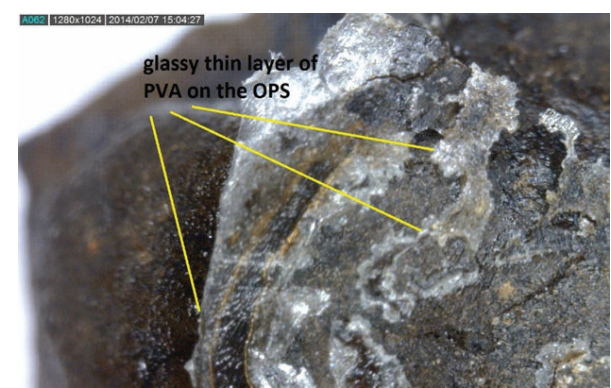

(b)

FIGURE 7: OPS aggregates soaked in polyvinyl alcohol.

The specimens were cured in an oven for 48 hours at $65^{\circ} \mathrm{C}$. After the specimens were removed from the oven, they were left at ambient conditions until test day. The room temperature and humidity were 28 to $31^{\circ} \mathrm{C}$ and $60 \%$, respectively. The samples were tested after 14 and 28 days, in accordance with ASTM C109. An average from three specimens was used to determine the compressive strength.

3.6. Preparation of Specimens for Different Curing Regime. An optimum A/FA ratio of 0.45 was selected for the OPSGPC produced by untreated OPS to investigate the effect of different curing temperatures (room temperature of $28^{\circ} \mathrm{C}, 50$, $65,80,95$, and $110^{\circ} \mathrm{C}$ ) and different periods. All specimens left at the ambient conditions after they were removed from the oven until the test day. They were taken out of the oven after $1,1.5,2,3,4,5,8$, and 10 days and cured at room temperature of 28 to $31^{\circ} \mathrm{C}$ until the test day.

\section{Results and Discussions}

4.1. Effect of Different Pretreatment on Water Absorption. Table 4 shows the various types of chemicals and concentration that were used in the investigation of their effect on the OPS. The clear $\mathrm{NaOH}$ solution that was used for soaking the OPS turned brown after 3 days. Similar treatment for OPS with $\mathrm{KOH}$ solution showed that the solution turned dark brown after 3 days. The surfaces of the OPS aggregates were covered with white colour deposit when subjected to soaking in $\mathrm{NaOH}$ and $\mathrm{KOH}$ solutions after 30 days. The OPS treated with PVA shows a thin glassy film formed around the OPS as shown in Figure 7. The same as $\mathrm{NaOH}$ and $\mathrm{KOH}$ alkaline solutions, the OPS aggregates soaked in sodium silicate solution showed similar results. The clear sodium silicate solution became light brown after the aggregates were soaked for 3 days, whereas the solution turned gelatine dark brown form after 5 days of soaking as shown in Figure 6(e). Soaking in alkaline solutions for 30 days has not showed much deterioration on the surface of the OPS aggregates. Mannan et al. also reported that $\mathrm{MgSO}_{4}$ solution has some deterioration effect on the OPS aggregates [35]. The water absorption values of both the pretreated and untreated OPS aggregates with different chemicals are shown in Table 5.

The water absorption values of the OPS pretreated with $5 \%, 20 \%$, and 50\% PVA solution were found as $50.04 \%$,
TABLE 5: Water absorption of pretreated and untreated OPS aggregates.

\begin{tabular}{lcc}
\hline SI & Designation & Water absorption (\%) \\
\hline 1 & A1 & 20.14 \\
2 & A2 & 19.85 \\
3 & A3 & 19.35 \\
\hline 4 & B1 & 19.88 \\
5 & B2 & 19.43 \\
6 & B3 & 18.76 \\
\hline 7 & C1 & 21.29 \\
8 & C2 & 20.91 \\
9 & C3 & 20.04 \\
\hline 10 & D1 & 11.30 \\
11 & D2 & 4.08 \\
12 & D3 & 4.03 \\
\hline 13 & E & 22.58 \\
\hline
\end{tabular}

$18.07 \%$, and $17.85 \%$, of the untreated OPS, respectively; this could be attributed to the thin film coating by PVA formed around the aggregates that prevent water absorption. The water absorption of the OPS pretreated with $20 \%$ and $50 \%$ was almost identical and hence it can be inferred that the pretreatment with $20 \%$ of PVA solution could be effective.

From Table 5, it can be seen that the effect of PVA is more evident than the alkaline solutions on the reduction of water absorption. The pretreated OPS aggregate with $20 \%$ and $50 \%$ of PVA solution decreases the water absorption by about $82 \%$ of the untreated OPS, while the pretreated alkaline solution of $\mathrm{NaOH}, \mathrm{KOH}$, and sodium silicate with the same concentration causes a decrease of about $14 \%, 17 \%$, and $11 \%$, respectively. Further, it can be seen from Table 5 that the reduction in the water absorption for the pretreated OPS aggregates with $\mathrm{NaOH}$ falls between the values of OPS aggregates pretreated with sodium silicate and $\mathrm{KOH}$ solutions. However, the pretreatment with $\mathrm{KOH}$ has better performance compared to the other two alkaline solutions.

4.2. Effect of Pretreatment of OPS on the Compressive Strength. The results of 3-, 7-, 14- and 28-day compressive strength test performed on specimens cured under both oven and ambient 
TABLE 6: Compressive strength of OPSGPC in different ages with different pretreated OPS.

\begin{tabular}{|c|c|c|c|c|c|c|c|c|c|}
\hline \multirow{3}{*}{ Serial number } & \multirow{3}{*}{ Designation } & \multicolumn{8}{|c|}{ Compressive strength $\left(\mathrm{N} / \mathrm{mm}^{2}\right)$} \\
\hline & & \multicolumn{4}{|c|}{ Ambient-cured specimens } & \multicolumn{4}{|c|}{ Oven-cured specimens } \\
\hline & & 3-day & 7-day & 14-day & 28-day & 3-day & 7-day & 14-day & 28-day \\
\hline 1 & A1 & 9.68 & 14.91 & 20.20 & 27.81 & 20.86 & 26.04 & 30.03 & 31.90 \\
\hline 2 & A2 & 9.89 & 14.97 & 20.32 & 27.84 & 20.99 & 26.45 & 30.25 & 32.44 \\
\hline 3 & A3 & 10.71 & 15.72 & 20.84 & 28.32 & 21.01 & 26.67 & 30.46 & 32.52 \\
\hline 4 & $\mathrm{~B} 1$ & 9.42 & 14.96 & 19.68 & 27.16 & 20.85 & 26.18 & 30.14 & 31.92 \\
\hline 5 & B2 & 9.88 & 15.12 & 20.09 & 27.86 & 21.03 & 26.66 & 30.33 & 32.48 \\
\hline 6 & B3 & 10.07 & 15.39 & 20.14 & 28.03 & 21.24 & 26.89 & 30.48 & 32.69 \\
\hline 7 & $\mathrm{C} 1$ & 9.54 & 14.95 & 19.68 & 26.98 & 20.68 & 26.03 & 30.10 & 31.89 \\
\hline 8 & C2 & 9.82 & 15.18 & 19.89 & 27.02 & 20.93 & 26.23 & 30.24 & 32.23 \\
\hline 9 & $\mathrm{C} 3$ & 10.08 & 15.23 & 20.01 & 27.12 & 21.12 & 26.39 & 30.51 & 32.37 \\
\hline 10 & $\mathrm{D} 1$ & 11.76 & 16.53 & 20.72 & 27.90 & 20.85 & 25.54 & 29.08 & 31.98 \\
\hline 11 & D2 & 12.56 & 17.86 & 21.19 & 30.08 & 21.07 & 25.63 & 29.23 & 32.14 \\
\hline 12 & D3 & 13.18 & 18.03 & 22.15 & 30.14 & 21.33 & 25.77 & 29.38 & 32.19 \\
\hline 13 & $\mathrm{E}$ & 9.36 & 14.77 & 19.46 & 19.46 & 20.27 & 25.95 & 29.89 & 31.87 \\
\hline
\end{tabular}

curing conditions are reported in Table 6 . The cube compressive strengths of ambient-cured specimens at the age of 14 days show that OPSGPC achieves the requisite compressive strength for structural grade lightweight concrete (SLWC) as per ACI 301-10 specifications.

However, the oven-cured specimens show better performance compared to ambient-cured specimens. The requisite cube compressive strength for SLWC of $20 \mathrm{MPa}$ could be achieved in 3 days for the oven-cured specimens and the 28day strength was about $32 \mathrm{MPa}$. The OPSGPC made from the OPS treated with 5\% sodium silicate solution showed the lowest compressive strength in ambient-cured condition and that one which made from the OPS treated with $50 \%$ PVA solution established the highest compressive strength; however, the compressive strength of both specimens with OPS treated with $20 \%$ and $50 \%$ PVA produced very close results. The difference in the 28-day compressive strength between the OPSGPC specimens produced from the OPS treated with alkaline solutions and the control specimen (Designation E), both cured in ambient condition, was only about $2.7 \%$; however, it was about $12 \%$ for the specimens made with OPS treated in $20 \%$ and $50 \%$ PVA solutions. This might be attributed to the reduction in the water absorption by the OPS as it was used as the aggregate in concrete. Figures 8 and 9 show the FESEM analysis image of ambientcured OPSGPC including pretreated OPS with PVA and $\mathrm{KOH}$, respectively. Figure 9 shows unreacted FA particles in geopolymer skeleton which cause a weaker geopolymer structure leading to lower compressive strength. This might be ascribed to the lack of alkaline activator solution due to absorption of OPS aggregates during the geopolymerization process.

In the oven-cured specimens, there was not much difference between the compressive strength at various ages among the OPSGPC specimens pretreated with different percentage of PVA solution. The geopolymerization is a process that takes place in a short duration and the oven curing condition

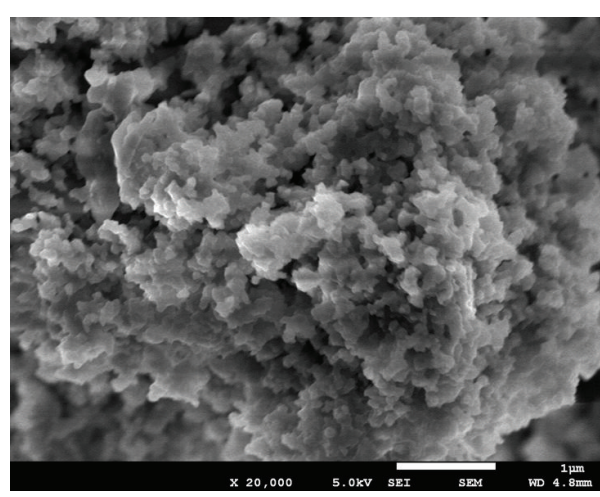

FIGURE 8: FESEM photography of ambient-cured OPSGPC incorporating pretreated OPS with PVA.

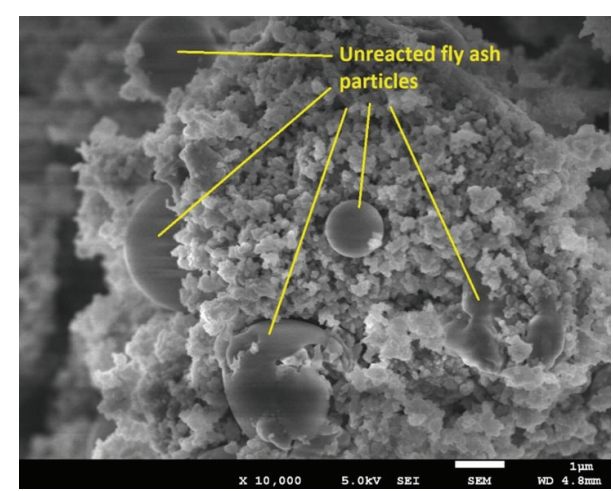

FIGURE 9: FESEM of ambient-cured OPSGPC incorporating pretreated OPS with $\mathrm{KOH}$.

enables this to be achieved [41] compared to the ambient curing condition. This implies that the longer duration of geopolymerization process has a direct effect on the absorption by OPS from the mortar; the longer processing time 


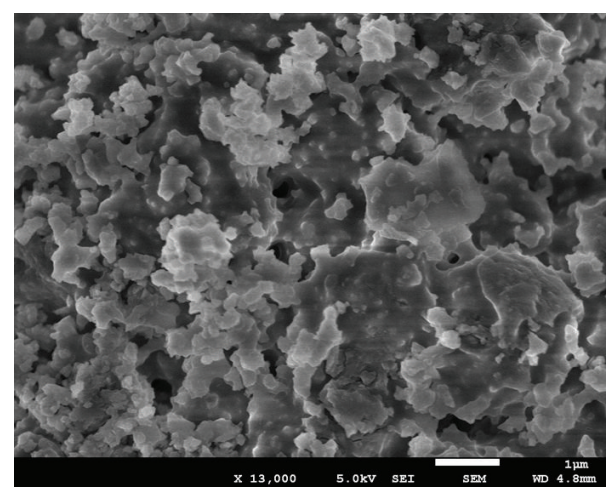

FIGURE 10: FESEM of ambient-cured OPSGPC incorporating pretreated OPS with $\mathrm{KOH}$.

might cause the OPS to absorb more alkaline activator solution and water and that will have direct effect on the reduction of the concentration of activator in the mortar, thus resulting in reduced compressive strength. It was also observed that the failure of the OPSGPC specimen in compression was not due to the bond failure between the OPS and the mortar, but rather due to crushing of OPS. In the OPS based concrete, the porous nature of aggregate enhanced the bond between OPS and matrix as the fine particles of binder penetrate the pores in the OPS that enhances the bond and hence improves the compressive strength [29]. They reported that improved performance of concrete when the compressive strength increased through formation of dense ITZ between the aggregate and binder matrix at higher superplasticizers (SP) dosage. However, the failure of the specimen is governed by the both the failure of OPS and the bond between the OPS and the matrix. The compressive strength is also governed by the convex and concave surfaces of OPS and the observation on the convex surface leads to the conclusion that its poor binding with matrix reduces the compressive strength. A comparison between the 28-day compressive strength results in Table 6 which depicts that the OPSGPC incorporating OPS pretreated with PVA solution produced the highest compressive strength compared to other pretreatments in ambientcured condition, while in the case of oven-cured specimens, the highest strength of about $33 \mathrm{MPa}$ was achieved for the OPSGPC produced with the OPS pretreated in $\mathrm{KOH}$ solution.

Figure 10 shows the FESEM analysis image of oven-cured OPSGPC including pretreated OPS in $\mathrm{KOH}$. More condensed geopolymer paste with fewer pores is obvious in this figure which leads to higher compressive strength than the ambientcured OPSGPCs. This might be attributed to the better geopolymerization process due to oven curing condition. It should be noted that the other specimens pretreated with alkaline and PVA solutions produced comparable strength. It means that pretreatment with alkaline solution in oven-cured condition leads to higher compressive strength in OPSGPC and pretreatment with PVA solution in ambient-cured condition causes higher compressive strength in OPSGPC.

4.3. Development of Compressive Strength. The 3-, 7-, and 14-day compressive strengths of ambient-cured OPSGPC specimens prepared with alkaline pretreated OPS were about $36 \%, 55 \%$, and $73 \%$ of 28 -day compressive strength, respectively, while for the specimens cured in oven, the corresponding percentages were about $65 \%, 82 \%$, and $94 \%$, respectively.

The 3-, 7-, and 14-day compressive strengths of ambient cured OPSGPC specimens prepared with PVA pretreated OPS were about $43 \%, 60 \%$, and $73 \%$ of 28 -day strength, respectively, whereas for oven cured specimens the corresponding values were about $66 \%, 80 \%$, and $91 \%$, respectively. For the ambient-cured OPSGPC specimens prepared with treated and untreated OPS, about $73 \%$ of 28 -day compressive strength was achieved in 14 days and the corresponding value for specimens cured in oven was $94 \%$. It can be concluded that the pretreatment of OPS has not much effect on the development of compressive strength in both ambient and oven cured conditions, compared to the specimens made with untreated OPS within the period of 28 days.

A comparison between the 28-day compressive strength of ambient-cured specimen prepared with alkaline pretreated and untreated OPS shows that OPS pretreated with 5\% sodium silicate has negligible effect on the compressive strength; the maximum increase in the compressive strength of about $5.5 \%$ was found for the specimen prepared with OPS pretreated with $50 \% \mathrm{NaOH}$. Similarly, for the oven cured specimens, the effect of the pretreatment was found negligible with the specimen pretreated with $50 \%$ of $\mathrm{KOH}$ showing an increase of $5 \%$. Moreover, the comparison between the ambient cured specimens prepared with PVA treated OPS and untreated OPS shows that the 3-, 7-, 14-, and 28-day compressive strengths of the former were about $41 \%, 22 \%$, $14 \%$, and $12 \%$, respectively, of the strength of the later. Thus, it can be concluded that the PVA treatment has some effect on the compressive strength if the specimens were cured in ambient condition.

4.4. Effect of Curing Method on the Compressive Strength. The observation on the ambient-cured OPSGPC specimens prepared based on different types of pretreated OPS showed that the specimens had not hardened early until 12 hours. Nevertheless, the physical observation revealed that the OPSGPC loses its plasticity within the few first hours of preparation of the specimen. However, for the specimens that were covered with the plastic wrapping and cured in an oven at $65^{\circ} \mathrm{C}$, the hardening took place in less than 2 hours.

The differences in the compressive strength between the 14- and 28-day for the OPSGPC made with and without treated OPS were $38 \%$ and $6.62 \%$ in the ambient and oven-cured conditions, respectively. The average differences between the 14 and 28-day strength of the oven-cured specimens for the OPS pre-treated with alkaline solutions and PVA solution were about $6.57 \%$ and $9.8 \%$, respectively. To achieve comparable strength to geopolymer concrete, it is necessary to cure geopolymer concrete with elevated temperature curing between 40 and $80^{\circ} \mathrm{C}$ for at least $6 \mathrm{~h}$ [43]. In most cases, $70 \%$ of the final compressive strength is developed in the first $12 \mathrm{~h}$ [41]. Therefore, most of the geopolymerisation takes place within the first 12 hours of heat curing and hence the compressive strength enhancement of OPSGPC between 14 and 28 days in oven-cured condition 


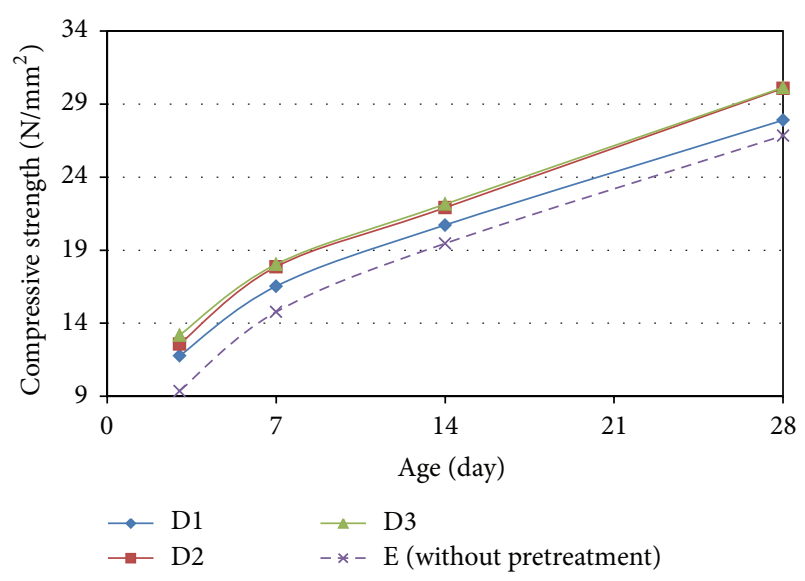

FIGURE 11: Compressive strength distribution for the OPSGPC with PVA solution treated OPS in ambient-cured condition.

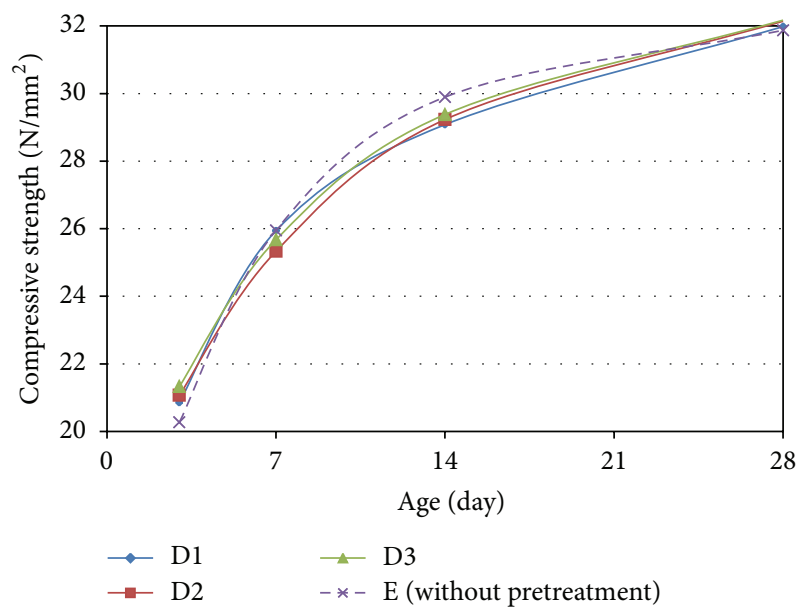

FIGURE 12: Development of compressive strength for the OPSGPC with PVA solution treated OPS in oven-cured condition.

was insignificant. A longer curing time improves the polymerisation process resulting in higher compressive strength. The previous study indicated that a longer curing time does not produce weaker concrete [10]. However, the increase in the compressive strength after 48 hours of oven curing is not significant [53].

Figures 11 and 12 show the development of the compressive strength up to a period of 28 days for the OPSGPC prepared with PVA pretreated OPS that was cured in ambient and oven conditions, respectively.

The average increase on the 28-day compressive strength was found to be about $1.25 \%$ and $2.72 \%$ for the oven and ambient-cured specimens, respectively, compared to the control specimens (designation E). Hence, it can be concluded that the pretreatment of OPS with alkaline solutions had no significant effect on the compressive strength in both the ambient and oven curing conditions; on the contrary, the PVA pretreatment of OPS has some effect on the compressive strength as $12 \%$ increase in the average 28 -day compressive strength was found for ambient-cured specimens. However, for oven-cured specimens the effect is negligible.

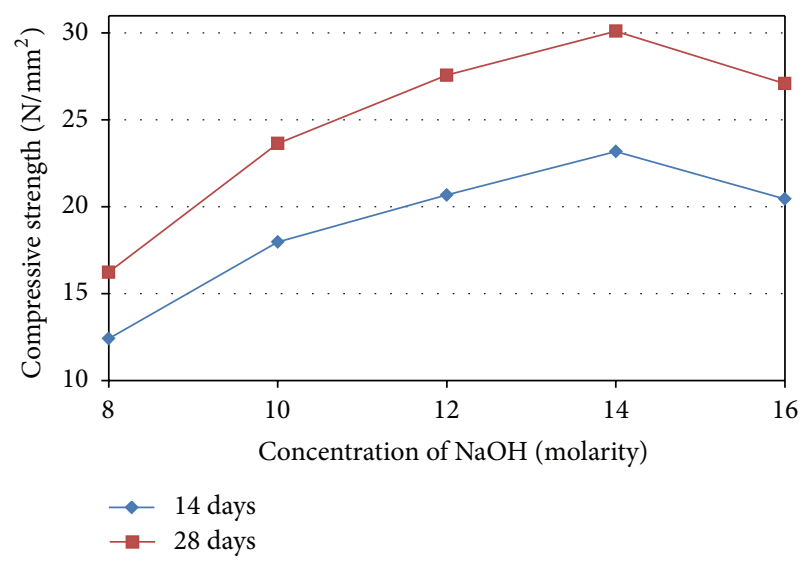

FIgURE 13: Influence of different concentrations of $\mathrm{NaOH}$ on the compressive strength of OPSGPC.

4.5. Influence of $\mathrm{NaOH}$ Concentration on the Compressive Strength and Density of OPSGPC. The compressive strength of geopolymers is directly connected to the degree of polymerization, which is strongly influenced by the soluble silicate and aluminate of the geopolymeric system. The dissolution of FA affected by concentration of alkaline solution and could be evaluated by measuring the leaching of $\mathrm{Al}^{3+}$ and $\mathrm{Si}^{4+}$ ions. Therefore, an important factor in controlling and evaluating the leaching of alumina and silica from FA particles is alkaline concentration, subsequent in geopolymerization and mechanical properties of hardened geopolymer [54]. In general, a higher degree of polymerization in the geopolymeric structures leads to higher compressive strength. The $\mathrm{NaOH}$ concentration in the aqueous phase of the geopolymeric process acts on the dissolution process [55]. The use of high concentrations of $\mathrm{NaOH}$ leads to greater dissolution of the initial solid materials and increases the geopolymerization reaction resulting in greater compressive strength [56]. Rattanasak and Chindaprasirt [54] conducted a study on the leaching of FA mixed with $\mathrm{NaOH}$ by measuring of $\mathrm{Si}^{4+}$ and $\mathrm{Al}^{3+}$ ions. They reported that $\mathrm{Si}^{4+}$ ion concentration for low and high molarity of $\mathrm{NaOH}$ was much less than that for the moderate concentration of $\mathrm{NaOH}$. For the high concentration of $\mathrm{NaOH}$, an increase in congealing of silica principally reduced the dissolution. Figure 13 shows the effect of sodium hydroxide concentrations on the compressive strength of OPSGPC. The mean compressive strength of the three test cubes for each molarity of alkaline activator at the age of 14 days and 28 days are presented in Figure 13. The test results shown in Figure 13 demonstrate that the compressive strength of OPSGPC increased steadily as the concentration of $\mathrm{NaOH}$ rose from $8 \mathrm{M}$ to $14 \mathrm{M}$. A maximum strength of about $30 \mathrm{MPa}$ was obtained at $14 \mathrm{M}$ concentration of $\mathrm{NaOH}$. It declined slightly to $27 \mathrm{MPa}$ when molarity rose to $16 \mathrm{M}$. Joshi and Kadu reported similar results [57]. The results of their study indicated that a substantial increase in the compressive strength when molarity was varied between $12 \mathrm{M}$ and $14 \mathrm{M}$.

In general, it was observed that high $\mathrm{NaOH}$ concentration in alkaline activator increases the compressive strength of the OPSGPC specimens. Conversely, the compressive strength 
decreased and it was observed that a part of activator solution remains unreacted and leached out and deposited onto the surface of specimens when the concentration of sodium hydroxide increased to $16 \mathrm{M}$. In geopolymer process, the concentration of $\mathrm{NaOH}$ in the alkaline activator has a significant effect on both the compressive strength and the microstructure of the geopolymers [58]. When an aluminum atom is bonded to four oxygen atoms, a negative charge is created. It is important that a neutral electrical state is sustained for hydroxysodalite geopolymer matrixes in the presence of cations such as $\mathrm{Na}^{+}$. Hydroxysodalite mixtures are composed of $\mathrm{SiO}_{4}$ and $\mathrm{AlO}_{4}$ tetrahedra that are linked together in an alternating fashion by sharing oxygen atoms. In order to counteract the negatively charged aluminum in the tetrahedron hydroxysodalite mixture, positive ions, such as those supplied by $\mathrm{Na}^{+}, \mathrm{K}^{+}, \mathrm{Li}^{+}, \mathrm{Ca}^{2+}, \mathrm{Ba}^{2+}, \mathrm{NH}^{4+}$, and $\mathrm{H}_{3} \mathrm{O}^{+}$, must be present. These components can be found in the cavities of the framework [59]. A weak dissolution was observed which was consistent with other geopolymerization processes that occurred at low alkaline activators [60]. Hence, an increase in alkaline concentration improved the geopolymerization process, which leads to more compressive strength for the OPSGPC.

As noted, the presence of cations, such as $\mathrm{Na}^{+}, \mathrm{K}^{+}$, and $\mathrm{Ca}^{2+}$, influences the state of the electrical charge and the catalytic properties in geopolymer systems [61]. When the $\mathrm{NaOH}$ concentration was increased, so too were the $\mathrm{Na}$ ions in the system. Subsequently, the $\mathrm{Na}$ ions were used to balance the charges and formed alumino-silicate networks [62]. However, the higher alkaline content in the geopolymers promoted greater solid dissolution but excess hydroxide ion concentration caused aluminosilicate gel precipitation in the early stages, hindering further geopolymerization and decreasing strength [63]. The decrease in the compressive strength at $16 \mathrm{M}$ could be related to higher alkaline content in the OPSGPC.

Alonso and Palomo [64] conducted a study on the rate of polymer formation, influenced by parameters such as curing temperature, alkaline concentration, and initial solids content. Their study indicated that high activator concentrations increased the $\mathrm{pH}$ in the liquid phase. Consequently, anionic forms of silicate were favoured and polymerization was delayed. They also reported that the resulting $\mathrm{pH}$ level was not conducive to stable molecular forms and it was more difficult to form the coagulated structure. They also discovered that $\mathrm{NaOH}$ concentrations above $10 \mathrm{M}$ caused lower rates of polymer formation resulting in decreasing mechanical strength.

The oven dry density depends on the sodium hydroxide concentration; higher concentration shows increase in the density. The specimens with a low density of $1744 \mathrm{~kg} / \mathrm{m}^{3}$ were prepared using $8 \mathrm{M}$ concentration of $\mathrm{NaOH}$ but the specimens made with $16 \mathrm{M}$ concentration of $\mathrm{NaOH}$ exhibited a maximum density of $1824 \mathrm{~kg} / \mathrm{m}^{3}$. Table 7 shows that the oven dry density of the OPSGPC varies from 1744 to $1824 \mathrm{~kg} / \mathrm{m}^{3}$. The increase in the density for specimens with high concentration of $\mathrm{NaOH}$ is attributed to the increase in the viscosity of the solution. In this study, the OPSGPC
TABLE 7: The density of OPSGPC in different molarities of alkali activator.

\begin{tabular}{lc}
\hline $\mathrm{NaOH}$ molarities & Density $\left(\mathrm{Kg} / \mathrm{m}^{3}\right)$ \\
\hline $8 \mathrm{M}$ & 1744 \\
$10 \mathrm{M}$ & 1753 \\
$12 \mathrm{M}$ & 1774 \\
$14 \mathrm{M}$ & 1798 \\
$16 \mathrm{M}$ & 1824 \\
\hline
\end{tabular}

mixtures with higher levels of sodium hydroxide were more cohesive. The increase in the density of the specimens with 8 to $12 \mathrm{M}$ concentration of $\mathrm{NaOH}$ was negligible.

4.6. Effect of Different A/FA Ratios on the Compressive Strength of OPSGPC. The compressive strengths of OPSGPC with different A/FA ratios are given in Table 8. For molarities less than $14 \mathrm{M}$, the rate of geopolymerisation increased as the ratio of A/FA increased from 0.2 to 0.35 , increasing the strength of the geopolymer specimens significantly. In contrast, there was only a slight increase in strength when the ratio rose from 0.35 to 0.45 . The maximum strength was reached when the A/FA ratio reached 0.45 . The results show that the compressive strength of OPSGPC made from a $14 \mathrm{M}$ concentration of $\mathrm{NaOH}$ in alkali activator increased as the A/FA ratio increased from 0.2 to 0.45 and reach a peak of about $30 \mathrm{MPa}$ at A/FA ratio of 0.45 .

The increase in the compressive strength depended on the nature of the complex chemical geopolymerisation process. The most important factor in the process is the amount of reactive silica because it is a major component of the structural framework of the reaction product that is the result of FA being activated by the alkali activator. Conditions that are highly alkaline dissolve reactive silicates to create polymeric $\mathrm{Si}-\mathrm{O}-\mathrm{Al}$ bonds [65].

One possible explanation for the increase in the compressive strength can be found in the higher amounts of sodium silicate solution. Higher amounts of this solution create more $\mathrm{SiO}_{2}$ species, which increases the ratio of $\mathrm{SiO}_{2} / \mathrm{Al}_{2} \mathrm{O}_{3}$ and more $\mathrm{Si}-\mathrm{O}-\mathrm{Si}$ bonds are formed. $\mathrm{Si}-\mathrm{O}-\mathrm{Si}$ bonds are stronger than $\mathrm{Si}-\mathrm{O}-\mathrm{Al}$ bonds [66] and their presence explains why the strength of geopolymers increases in these situations.

Figure 14 shows the influence of the A/FA ratio on the compressive strength of OPSGPC for different concentrations of $\mathrm{NaOH}$ in alkali activator solution. In general, a slight decrease in the compressive strength was noticed for specimens with A/FA ratio from 0.45 to 0.55 as shown in Figure 14 .

A possible explanation for the decrease in the compressive strength of OPSGPC may be found in the relationship between the increase in total water content in geopolymer paste and A/FA ratios higher than 0.45 . Water is essential in geopolymerisation process, especially for the destruction of solid particles and the hydrolysis of dissolved ions ( $\mathrm{Al}$ and $\mathrm{Si}$ ). Water is the reactant in the dissolving part of process, and if the $\mathrm{OH}^{-}$concentration is high enough, then the addition of more water will increase dissolution and hydrolysis. Water also acts as a product in the geopolymerisation process; however, too much water can hinder the geopolymerisation 
TABLE 8: Compressive strength of OPSGPC in different A/FA ratios (OPS used in saturated surface dry (SSD) conditions, mix proportion $1 / 0.74 / 0.66\left(\mathrm{FA} / \mathrm{sand} / \mathrm{OPS}\right.$ ) by weight, $\mathrm{FA}=480 \mathrm{Kg} / \mathrm{m}^{3}, \mathrm{~W} / \mathrm{FA}=0.37$, and $\left.\mathrm{SP}=9.5 \mathrm{~L} / \mathrm{m}^{3}\right)$.

\begin{tabular}{|c|c|c|c|c|c|c|c|c|c|c|c|}
\hline \multirow{3}{*}{ Mix order } & \multirow{3}{*}{ A/FA ratio } & \multicolumn{10}{|c|}{ Compressive strength $\left(\mathrm{N} / \mathrm{mm}^{2}\right)$} \\
\hline & & \multicolumn{2}{|c|}{$8 \mathrm{Mol}$ solution } & \multicolumn{2}{|c|}{10 Mol solution } & \multicolumn{2}{|c|}{$12 \mathrm{Mol}$ solution } & \multicolumn{2}{|c|}{$14 \mathrm{Mol}$ solution } & \multicolumn{2}{|c|}{$16 \mathrm{Mol}$ solution } \\
\hline & & 14-day & 28-day & 14-day & 28-day & 14-day & 28-day & 14-day & 28-day & 14-day & 28-day \\
\hline $\mathrm{A} 1$ & 0.20 & 6.91 & 13.04 & 7.84 & 14.18 & 9.15 & 16.07 & 13.75 & 19.84 & 17.31 & 23.44 \\
\hline A2 & 0.25 & 8.02 & 15.51 & 9.98 & 17.64 & 11.41 & 19.26 & 16.27 & 23.76 & 19.49 & 26.15 \\
\hline A3 & 0.30 & 9.46 & 17.47 & 11.08 & 20.33 & 14.66 & 23.10 & 19.09 & 27.98 & 20.56 & 28.58 \\
\hline A4 & 0.35 & 9.84 & 19.13 & 12.44 & 22.92 & 15.97 & 25.94 & 21.77 & 31.12 & 22.82 & 30.17 \\
\hline A5 & 0.40 & 10.63 & 19.68 & 12.84 & 23.11 & 16.22 & 26.42 & 22.43 & 31.93 & 22.91 & 30.43 \\
\hline A6 & 0.45 & 10.84 & 20.26 & 13.04 & 23.82 & 16.37 & 27.03 & 22.57 & 32.42 & 21.06 & 29.53 \\
\hline A7 & 0.50 & 10.23 & 19.49 & 13.48 & 23.98 & 16.91 & 27.47 & 21.14 & 31.08 & 20.31 & 28.65 \\
\hline A8 & 0.55 & 10.18 & 19.02 & 12.49 & 23.02 & 16.36 & 26.94 & 20.87 & 30.41 & 19.29 & 27.39 \\
\hline
\end{tabular}

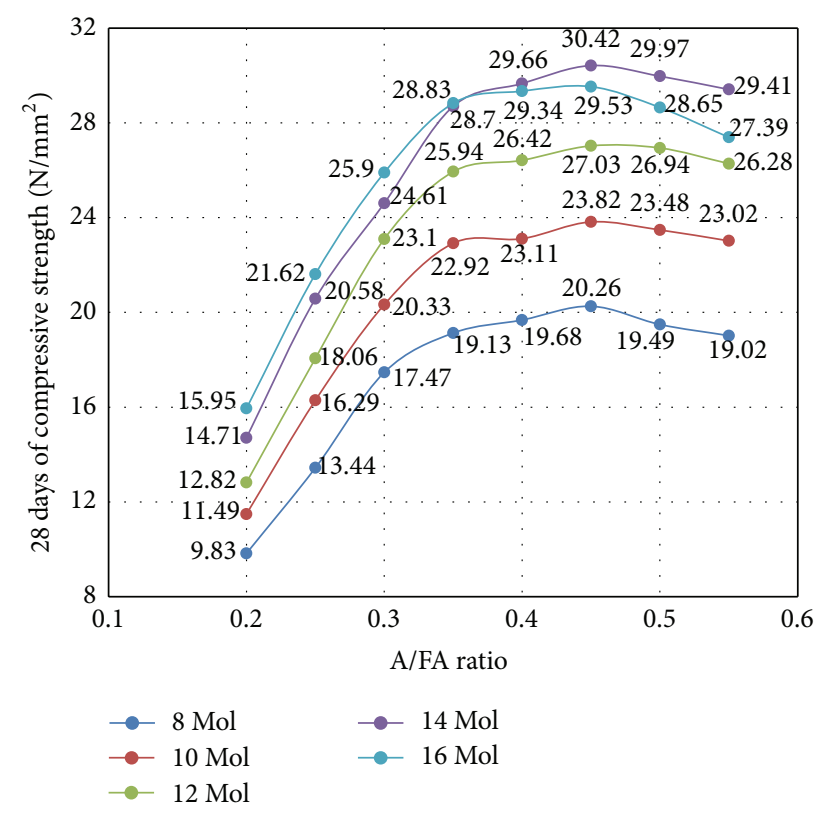

FIGURE 14: Influence of different A/FA ratios on the compressive strength of OPSGPC at different molarities.

process. Water is a critical factor; too much or too little will affect the geopolymerisation rate, resulting in decreased strength.

4.7. Effect of Different Curing Regimes on the Compressive Strength of OPSGPC. The temperature, curing period, and relative humidity are the curing conditions that impact the creation of microstructures and they can affect the mechanical characteristics of alkaline-activated FA [51]. The compressive strength of OPSGPC specimens exposed to different curing temperatures is shown in Figure 15. The specimens cured at $65^{\circ} \mathrm{C}$ had a maximum compressive strength of about $33 \mathrm{MPa}$ after only 4 days of curing period. In contrast, the lowest compressive strength of $6.45 \mathrm{MPa}$ was obtained for specimen cured at $110^{\circ} \mathrm{C}$ for 10 days. For specimens cured at $65^{\circ} \mathrm{C}$, an increase in curing period up to 4 days causes

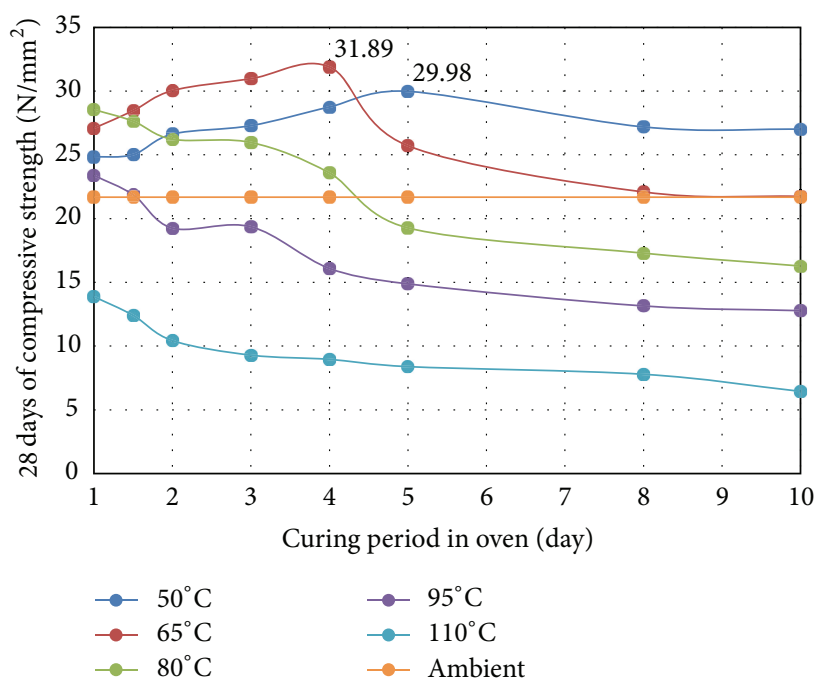

FIGURE 15: Compressive strength of OPSGPC at different curing temperatures for different curing periods (the specimens were kept in ambient condition after oven curing period till the test day of the 28 days).

a steady increase in the compressive strength. However, further increase in curing period beyond 4 days produces less compressive strength. The curing period more than 8 days resulted in a short decrease of compressive strength. However, the compressive strength of specimens gradually decreased when cured at temperatures higher than $65^{\circ} \mathrm{C}$.

Hardjito and Rangan [67] found that the compressive strength of FA based geopolymers did not develop significantly when cured at temperatures in excess of $60^{\circ} \mathrm{C}$ and they recommended that FA based geopolymers should be cured at $65^{\circ} \mathrm{C}$. Chindaprasirt et al. [68] conducted a study that looked at the relationship between moisture and the strength produced by the geopolymerization process. They found that the increase in the curing temperature caused their specimens to lose a large amount of moisture, which could undermine the strength of the specimen because the process requires moisture to improve the strength of the final product. Al Bakri et al. [69] used FTIR spectra analysis and found that 
the higher the Si content of the specimens cured at $60^{\circ} \mathrm{C}$, the higher their compressive strength.

Figure 15 also shows the steady raise in the strength for specimens cured at $50^{\circ} \mathrm{C}$. Here the peak of about $30 \mathrm{MPa}$ in compressive strength was reached after 5 days of curing period. There was also a slight increase after 1.5 days, followed by a decrease after 5 days of curing period in the compressive strength. However, the decrease of the 10 days of oven curing period was found to be about $10 \%$.

A study was conducted by Rovnaník [70] to study the compressive strength of geopolymers cured at temperatures ranging from $10^{\circ} \mathrm{C}$ to $80^{\circ} \mathrm{C}$. He reported that geopolymers cured at $10^{\circ} \mathrm{C}, 20^{\circ} \mathrm{C}$, and $40^{\circ} \mathrm{C}$ were stronger than those cured at temperatures of $60^{\circ} \mathrm{C}$ or higher. Figure 5 shows the curing temperatures of $80^{\circ} \mathrm{C}$ and $95^{\circ} \mathrm{C}$ resulting in the compressive strength of OPSGPC declining steadily for the first 2 days. The decrease in the compressive strength of specimens cured at a temperature of $110^{\circ} \mathrm{C}$ for 1 day to 10 days was found to be about $54 \%$.

The results illustrated in Figure 15 indicate that a longer hotter curing period has a negative effect on the strength of the geopolymers, especially for specimens cured at temperatures greater than $65^{\circ} \mathrm{C}$. These results are supported by claims made by other researchers [67-69]. For instance, van Jaarsveld et al. [10] claimed that longer and hotter curing times would lead to weaker geopolymer structures. They believed that curing temperatures in excess of $100^{\circ} \mathrm{C}$ had a negative effect on the geopolymer structures. One explanation for the loss of strength is that the aggregates and the geopolymer matrix expand when the temperature increases [71]. The compressive strength of specimens heatcured for less than 4 days at temperatures below $80^{\circ} \mathrm{C}$ was higher than those cured at ambient temperatures.

\section{Conclusions}

The research findings of OPS pretreated with four different chemicals in three different percentages (5\%, 20\%, and 50\%) are presented in this paper. These chemicals were used to investigate the effect of alkaline activators solutions and PVA solution on the water absorption and the compressive strength up to a period of 28 days in two different curing environments. This paper also reports the results of an experimental investigation on the effect of different concentrations of $\mathrm{NaOH}$ in the alkaline activator solution, alkaline activator to $\mathrm{FA}$ content $(\mathrm{A} / \mathrm{FA})$ ratio, and the curing regime on the compressive strength and density of OPSGPC. The molarity of $\mathrm{NaOH}$ was varied between $8 \mathrm{M}$ and $16 \mathrm{M}$; the A/FA ratio and the curing temperature were varied in the range of 0.2 to 0.55 and $55^{\circ} \mathrm{C}$ to $110^{\circ} \mathrm{C}$, respectively. The specimens were cured at different temperatures for the period of 1 day to 10 days and then kept in ambient condition of 28 to $31^{\circ} \mathrm{C}$ temperature and $60 \%$ humidity. Based on the tests and the results obtained, the following conclusions were drawn.

(1) The 24-hour water absorption value for OPS pretreated with $20 \%$ and $50 \%$ PVA was about $4 \%$ compared to $23 \%$ for untreated OPS. Thus it can be concluded that PVA solution with $20 \%$ concentration is sufficient to reduce the water absorption of OPS.

(2) The OPSGPC specimens produced using OPS treated with $20 \%$ PVA solution produced the 28-day compressive strength of about $30 \mathrm{MPa}$ in ambient-cured condition.

(3) Pretreatment with alkaline solution in oven cured condition leads to higher compressive strength in OPSGPC and pretreatment with PVA solution in ambient-cured condition cause higher compressive strength in OPSGPC.

(4) The alkaline pretreatment of OPS did not have any significant effect on the compressive strength of OPSGPC in both the ambient and oven curing conditions.

(5) The pretreatment of OPS with $20 \%$ and 50\% PVA solution enhanced the compressive strength of OPSGPC in ambient curing condition by $12 \%$ as the PVA coating reduces the water absorption; however, in the oven-cured condition the effect of PVA coating is negligible which could be attributed to early development of geopolymerization.

(6) Almost all the specimens achieved about $60 \%$ and $80 \%$ of the 28 -day compressive strengths in 7 days for ambient and the oven-cured specimens, respectively.

(7) The effect of concentration of $\mathrm{NaOH}$ in alkaline activator (molarity) on the compressive strength showed an increase up to $14 \mathrm{M}$; however, there is a decrease at $16 \mathrm{M}$ in the compressive strength of OPSGPC.

(8) The oven dry density of OPSGPC was found to increase by increasing in the $\mathrm{NaOH}$ concentrations.

(9) The highest compressive strength of $32 \mathrm{MPa}$ was obtained for the A/FA ratio of 0.45 and higher water content in the A/FA ratio beyond 0.45 reduced the compressive strength.

(10) In general, the A/FA ratio between 0.35 and 0.45 is recommended to produce structural grade OPSGPC.

(11) Even though the highest compressive strength of $32 \mathrm{MPa}$ was obtained for specimens cured at $65^{\circ} \mathrm{C}$ and 4 days of curing period, the curing period of 2 days at temperature of $65^{\circ} \mathrm{C}$ was found to produce compressive strength of $30 \mathrm{Mpa}$ and is recommended for OPSGPC.

\section{Conflict of Interests}

The authors declare that there is no conflict of interests regarding the publication of this paper.

\section{Acknowledgment}

This research work was funded by the University of Malaya under High Impact Research Grant (HIRG) no. UM.C/HIR/MOHE/ENG/02/D000002-16001 (synthesis of blast resistant structures). 


\section{References}

[1] M. Aly, M. S. J. Hashmi, A. G. Olabi, M. Messeiry, E. F. Abadir, and A. I. Hussain, "Effect of colloidal nano-silica on the mechanical and physical behaviour of waste-glass cement mortar," Materials and Design, vol. 33, no. 1, pp. 127-135, 2012.

[2] S. Aydin and B. Baradan, "Mechanical and microstructural properties of heat cured alkali-activated slag mortars," Materials \& Design, vol. 35, pp. 374-383, 2012.

[3] R. Siddique, "Performance characteristics of high-volume Class F fly ash concrete," Cement and Concrete Research, vol. 34, no. 3, pp. 487-493, 2004.

[4] S. Zahi and A. R. Daud, "Fly ash characterization and application in Al-based Mg alloys," Materials and Design, vol. 32, no. 3, pp. 1337-1346, 2011.

[5] A. Medina, P. Gamero, X. Querol et al., "Fly ash from a Mexican mineral coal I: mineralogical and chemical characterization," Journal of Hazardous Materials, vol. 181, no. 1-3, pp. 82-90, 2010.

[6] X. Guo, H. Shi, L. Chen, and W. A. Dick, "Alkali-activated complex binders from class $\mathrm{C}$ fly ash and Ca-containing admixtures," Journal of Hazardous Materials, vol. 173, no. 1-3, pp. 480-486, 2010.

[7] J. Temuujin, A. van Riessen, and R. Williams, "Influence of calcium compounds on the mechanical properties of fly ash geopolymer pastes," Journal of Hazardous Materials, vol. 167, no. 1-3, pp. 82-88, 2009.

[8] A. R. Sakulich, "Reinforced geopolymer composites for enhanced material greenness and durability," Sustainable Cities and Society, vol. 1, no. 4, pp. 195-210, 2011.

[9] J. Wongpa, K. Kiattikomol, C. Jaturapitakkul, and P. Chindaprasirt, "Compressive strength, modulus of elasticity, and water permeability of inorganic polymer concrete," Materials and Design, vol. 31, no. 10, pp. 4748-4754, 2010.

[10] J. G. S. van Jaarsveld, J. S. J. van Deventer, and G. C. Lukey, “The effect of composition and temperature on the properties of fly ash- and kaolinite-based geopolymers," Chemical Engineering Journal, vol. 89, no. 1-3, pp. 63-73, 2002.

[11] J. G. S. Van Jaarsveld, J. S. J. Van Deventer, and G. C. Lukey, "The characterisation of source materials in fly ash-based geopolymers," Materials Letters, vol. 57, no. 7, pp. 1272-1280, 2003.

[12] V. F. F. Barbosa, K. J. D. MacKenzie, and C. Thaumaturgo, "Synthesis and characterisation of materials based on inorganic polymers of alumina and silica: sodium polysialate polymers," International Journal of Inorganic Materials, vol. 2, no. 4, pp. 309-317, 2000.

[13] W. M. Kriven and J. L. Bell, "Effect of alkali choice on geopolymer properties," in Proceedings of the 28th International Conference on Advanced Ceramics and Composites, vol. 25, pp. 99-104, January 2004.

[14] W. M. Kriven, J. L. Bell, and M. Gordon, "Geopolymer refractories for the glass manufacturing industry," Ceramic Engineering and Science Proceedings, vol. 25, pp. 57-79, 2004.

[15] T. Hanzlíček, M. Steinerová, P. Straka, I. Perná, P. Siegl, and T. Švarcová, "Reinforcement of the terracotta sculpture by geopolymer composite," Materials \& Design, vol. 30, no. 8, pp. 3229-3234, 2009.

[16] J. Davidovits, Geopolymer Chemistry and Applications, 3rd edition, 2011.

[17] T. Bakharev, "Resistance of geopolymer materials to acid attack," Cement and Concrete Research, vol. 35, no. 4, pp. 658-670, 2005.
[18] J. G. S. van Jaarsveld and J. S. J. van Deventer, "Effect of the alkali metal activator on the properties of fly ash-based geopolymers," Industrial and Engineering Chemistry Research, vol. 38, no. 10, pp. 3932-3941, 1999.

[19] S. Songpiriyakij, T. Pulngern, P. Pungpremtrakul, and C. Jaturapitakkul, "Anchorage of steel bars in concrete by geopolymer paste," Materials and Design, vol. 32, no. 5, pp. 3021-3028, 2011.

[20] M. Olivia and H. Nikraz, "Properties of fly ash geopolymer concrete designed by Taguchi method," Materials and Design, vol. 36, pp. 191-198, 2012.

[21] A. Nazari, H. Khanmohammadi, M. Amini, H. Hajiallahyari, and A. Rahimi, "Production geopolymers by Portland cement: designing the main parameters' effects on compressive strength by Taguchi method," Materials \& Design, vol. 41, pp. 43-49, 2012.

[22] S. Riahi, A. Nazari, D. Zaarei, G. Khalaj, H. Bohlooli, and M. M. Kaykha, "Compressive strength of ash-based geopolymers at early ages designed by Taguchi method," Materials and Design, vol. 37, pp. 443-449, 2012.

[23] A. Nazari, S. Riahi, and A. Bagheri, "Designing water resistant lightweight geopolymers produced from waste materials," Materials and Design, vol. 35, pp. 296-302, 2012.

[24] P. K. Sarker, R. Haque, and K. V. Ramgolam, "Fracture behaviour of heat cured fly ash based geopolymer concrete," Materials and Design, vol. 44, pp. 580-586, 2013.

[25] V. Sata, A. Wongsa, and P. Chindaprasirt, "Properties of pervious geopolymer concrete using recycled aggregates," Construction and Building Materials, vol. 42, pp. 33-39, 2013.

[26] B. Joseph and G. Mathew, "Influence of aggregate content on the behavior of fly ash based geopolymer concrete," Scientia Iranica, vol. 19, no. 5, pp. 1188-1194, 2012.

[27] R. H. Kupaei, U. J. Alengaram, M. Z. B. Jumaat, and H. Nikraz, "Mix design for fly ash based oil palm shell geopolymer lightweight concrete," Construction and Building Materials, vol. 43, pp. 490-496, 2013.

[28] P. Shafigh, H. Mahmud, and M. Z. Jumaat, "Effect of steel fiber on the mechanical properties of oil palm shell lightweight concrete," Materials and Design, vol. 32, no. 7, pp. 3926-3932, 2011.

[29] U. J. Alengaram, H. Mahmud, and M. Z. Jumaat, "Enhancement and prediction of modulus of elasticity of palm kernel shell concrete," Materials and Design, vol. 32, no. 4, pp. 2143-2148, 2011.

[30] P. Shafigh, H. B. Mahmud, and M. Z. Jumaat, "Oil palm shell lightweight concrete as a ductile material," Materials and Design, vol. 36, pp. 650-654, 2012.

[31] M. Z. Jumaat, U. J. Alengaram, and H. Mahmud, "Shear strength of oil palm shell foamed concrete beams," Materials \& Design, vol. 30, no. 6, pp. 2227-2236, 2009.

[32] U. Johnson Alengaram, M. Z. Jumaat, H. Mahmud, and M. M. Fayyadh, "Shear behaviour of reinforced palm kernel shell concrete beams," Construction and Building Materials, vol. 25, no. 6, pp. 2918-2927, 2011.

[33] U. J. Alengaram, B. A. Al Muhit, and M. Z. B. Jumaat, "Utilization of oil palm kernel shell as lightweight aggregate in concrete-a review," Construction and Building Materials, vol. 38, pp. 161-172, 2013.

[34] P. Shafigh, M. Z. Jumaat, H. B. Mahmud, and U. J. Alengaram, "A new method of producing high strength oil palm shell lightweight concrete," Materials and Design, vol. 32, no. 10, pp. 4839-4843, 2011. 
[35] M. A. Mannan, J. Alexander, C. Ganapathy, and D. C. L. Teo, "Quality improvement of oil palm shell (OPS) as coarse aggregate in lightweight concrete," Building and Environment, vol. 41, no. 9, pp. 1239-1242, 2006.

[36] A. R. Brough and A. Atkinson, "Automated identification of the aggregate-paste interfacial transition zone in mortars of silica sand with Portland or alkali-activated slag cement paste," Cement and Concrete Research, vol. 30, no. 6, pp. 849-854, 2000.

[37] S. Demie, M. F. Nuruddin, and N. Shafiq, "Effects of microstructure characteristics of interfacial transition zone on the compressive strength of self-compacting geopolymer concrete," Construction and Building Materials, vol. 41, pp. 91-98, 2013.

[38] D. L. Y. Kong and J. G. Sanjayan, "Damage behavior of geopolymer composites exposed to elevated temperatures," Cement and Concrete Composites, vol. 30, no. 10, pp. 986-991, 2008.

[39] G. Kovalchuk, A. Fernández-Jiménez, and A. Palomo, "Alkaliactivated fly ash: effect of thermal curing conditions on mechanical and microstructural development-part II," Fuel, vol. 86, no. 3, pp. 315-322, 2007.

[40] M. Criado, A. Palomo, and A. Fernández-Jiménez, "Alkali activation of fly ashes. Part 1: effect of curing conditions on the carbonation of the reaction products," Fuel, vol. 84, no. 16, pp. 2048-2054, 2005.

[41] Z. Yunsheng, S. Wei, C. Qianli, and C. Lin, "Synthesis and heavy metal immobilization behaviors of slag based geopolymer," Journal of Hazardous Materials, vol. 143, no. 1-2, pp. 206-213, 2007.

[42] D. Hardjito, S. E. Wallah, D. M. J. Sumajouw, and B. V. Rangan, "On the development of fly ash-based geopolymer concrete," ACI Materials Journal, vol. 101, no. 6, pp. 467-472, 2004.

[43] A. Palomo, M. W. Grutzeck, and M. T. Blanco, "Alkali-activated fly ashes: a cement for the future," Cement and Concrete Research, vol. 29, no. 8, pp. 1323-1329, 1999.

[44] F. Škvára, L. Kopecký, V. Šmilauer, and Z. Bittnar, "Material and structural characterization of alkali activated low-calcium brown coal fly ash," Journal of Hazardous Materials, vol. 168, no. 2-3, pp. 711-720, 2009.

[45] J. Temuujin, R. P. Williams, and A. van Riessen, "Effect of mechanical activation of fly ash on the properties of geopolymer cured at ambient temperature," Journal of Materials Processing Technology, vol. 209, no. 12-13, pp. 5276-5280, 2009.

[46] D. Hardjito, C. C. Cheak, and C. H. L. Ing, "Strength and setting times of low calcium fly ash-based geopolymer mortar," Modern Applied Science, vol. 2, no. 4, pp. 3-11, 2008.

[47] D. L. Y. Kong and J. G. Sanjayan, "Effect of elevated temperatures on geopolymer paste, mortar and concrete," Cement and Concrete Research, vol. 40, no. 2, pp. 334-339, 2010.

[48] D. L. Y. Kong, J. G. Sanjayan, and K. Sagoe-Crentsil, "Comparative performance of geopolymers made with metakaolin and fly ash after exposure to elevated temperatures," Cement and Concrete Research, vol. 37, no. 12, pp. 1583-1589, 2007.

[49] E. N. Kani, A. Allahverdi, and J. L. Provis, "Efflorescence control in geopolymer binders based on natural pozzolan," Cement and Concrete Composites, vol. 34, no. 1, pp. 25-33, 2012.

[50] M. Criado, A. Palomo, A. Fernández-Jiménez, and P. F. G. Banfill, "Alkali activated fly ash: effect of admixtures on paste rheology," Rheologica Acta, vol. 48, no. 4, pp. 447-455, 2009.

[51] M. Komljenović, Z. Baščarević, and V. Bradić, "Mechanical and microstructural properties of alkali-activated fly ash geopolymers," Journal of Hazardous Materials, vol. 181, no. 1-3, pp. 3542, 2010.
[52] H. Xu and J. S. J. van Deventer, "The geopolymerisation of alumino-silicate minerals," International Journal of Mineral Processing, vol. 59, no. 3, pp. 247-266, 2000.

[53] D. Hardjito, S. E. Wallah, D. M. J. Sumajouw, and B. V. Rangan, "Factors influencing the compressive strength of fly ash-based geopolymer concrete," Civil Engineering Dimension, vol. 6, pp. 88-93, 2004.

[54] U. Rattanasak and P. Chindaprasirt, "Influence of $\mathrm{NaOH}$ solution on the synthesis of fly ash geopolymer," Minerals Engineering, vol. 22, no. 12, pp. 1073-1078, 2009.

[55] D. Panias, I. P. Giannopoulou, and T. Perraki, "Effect of synthesis parameters on the mechanical properties of fly ashbased geopolymers," Colloids and Surfaces A: Physicochemical and Engineering Aspects, vol. 301, no. 1-3, pp. 246-254, 2007.

[56] F. A. Memon, M. F. Nuruddin, S. Khan, N. Shafiq, and T. Ayub, "Effect of sodium hydroxide concentration on fresh properties and compressive strength of self-compacting geopolymer concrete," Journal of Engineering Science and Technology, vol. 8, no. 1, pp. 44-56, 2013.

[57] S. V. Joshi and M. S. Kadu, "Role of alkaline activator in development of eco-friendly fly ash based geo polymer concrete," International Journal of Environmental Science and Development, vol. 3, no. 5, 2012.

[58] K. Somna, C. Jaturapitakkul, P. Kajitvichyanukul, and P. Chindaprasirt, "NaOH-activated ground fly ash geopolymer cured at ambient temperature," Fuel, vol. 90, no. 6, pp. 2118-2124, 2011.

[59] R. I. Yousef, B. El-Eswed, M. Alshaaer, F. Khalili, and H. Khoury, "The influence of using Jordanian natural zeolite on the adsorption, physical, and mechanical properties of geopolymers products," Journal of Hazardous Materials, vol. 165, no. 1-3, pp. 379-387, 2009.

[60] M. Izquierdo, X. Querol, J. Davidovits, D. Antenucci, H. Nugteren, and C. Fernández-Pereira, "Coal fly ash-slag-based geopolymers: microstructure and metal leaching," Journal of Hazardous Materials, vol. 166, no. 1, pp. 561-566, 2009.

[61] P. Bankowski, L. Zou, and R. Hodges, "Reduction of metal leaching in brown coal fly ash using geopolymers," Journal of Hazardous Materials, vol. 114, no. 1-3, pp. 59-67, 2004.

[62] A. Sathonsaowaphak, P. Chindaprasirt, and K. Pimraksa, "Workability and strength of lignite bottom ash geopolymer mortar," Journal of Hazardous Materials, vol. 168, no. 1, pp. 4450, 2009.

[63] W. K. W. Lee and J. S. J. van Deventer, "The effects of inorganic salt contamination on the strength and durability of geopolymers," Colloids and Surfaces A: Physicochemical and Engineering Aspects, vol. 211, no. 2-3, pp. 115-126, 2002.

[64] S. Alonso and A. Palomo, "Alkaline activation of metakaolin and calcium hydroxide mixtures: influence of temperature, activator concentration and solids ratio," Materials Letters, vol. 47, no. 1-2, pp. 55-62, 2001.

[65] A. Fernández-Jiménez and A. Palomo, "Characterisation of fly ashes. Potential reactivity as alkaline cements," Fuel, vol. 82, no. 18, pp. 2259-2265, 2003.

[66] A. M. Mustafa Al Bakri, H. Kamarudin, A. K. Omar, M. N. Norazian, C. M. Ruzaidi, and A. R. Rafiza, "The effect of alkaline activator ratio on the compressive strength of fly ash-based geopolymers," Australian Journal of Basic and Applied Sciences, vol. 5, no. 9, pp. 1916-1922, 2011.

[67] D. Hardjito and B. V. Rangan, "Development and properties of low-calcium fly ash based geopolymer concrete," Research report GC 1, Faculty of Engineering, Curtin University of Technology, Perth, Australia, 2005. 
[68] P. Chindaprasirt, T. Chareerat, and V. Sirivivatnanon, "Workability and strength of coarse high calcium fly ash geopolymer," Cement and Concrete Composites, vol. 29, no. 3, pp. 224-229, 2007.

[69] A. M. M. Al Bakri, H. Kamarudin, M. BinHussain, I. Khairul Nizar, Y. Zarin, and A. R. Rafiza, "The effect of curing temperature on physical and chemical properties of geopolymers," Physics Procedia, vol. 22, pp. 286-291, 2011.

[70] P. Rovnaník, "Effect of curing temperature on the development of hard structure of metakaolin-based geopolymer," Construction and Building Materials, vol. 24, no. 7, pp. 1176-1183, 2010.

[71] H. Xu, Q. Li, L. Shen, W. Wang, and J. Zhai, "Synthesis of thermostable geopolymer from circulating fluidized bed combustion (CFBC) bottom ashes," Journal of Hazardous Materials, vol. 175, no. 1-3, pp. 198-204, 2010. 

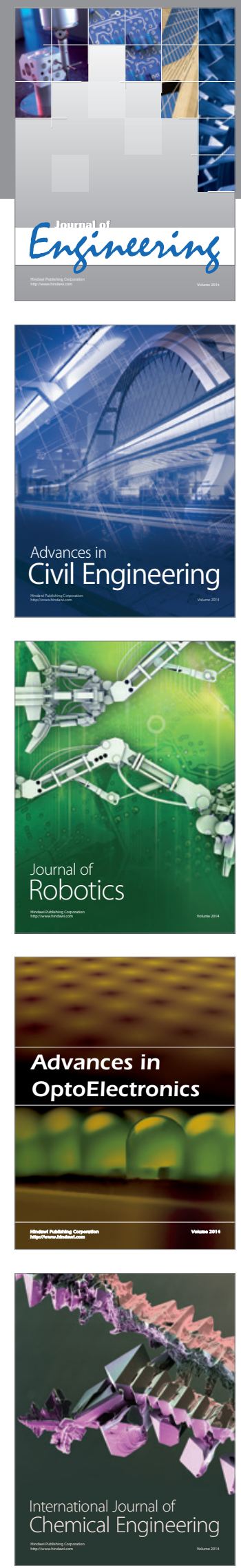

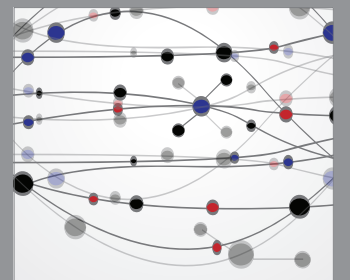

The Scientific World Journal
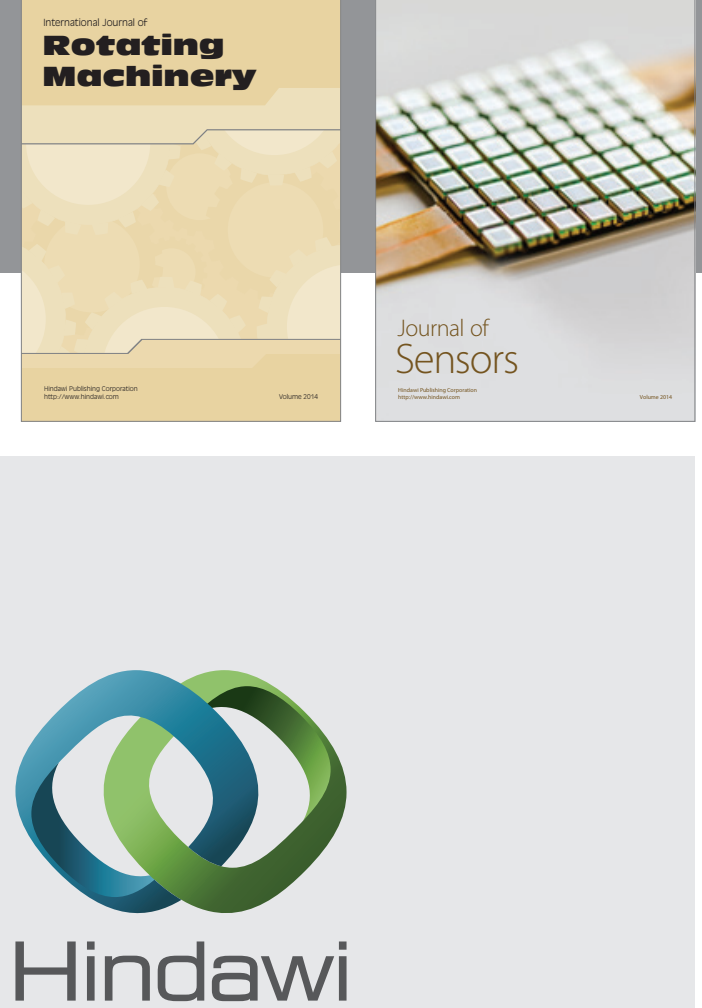

Submit your manuscripts at http://www.hindawi.com
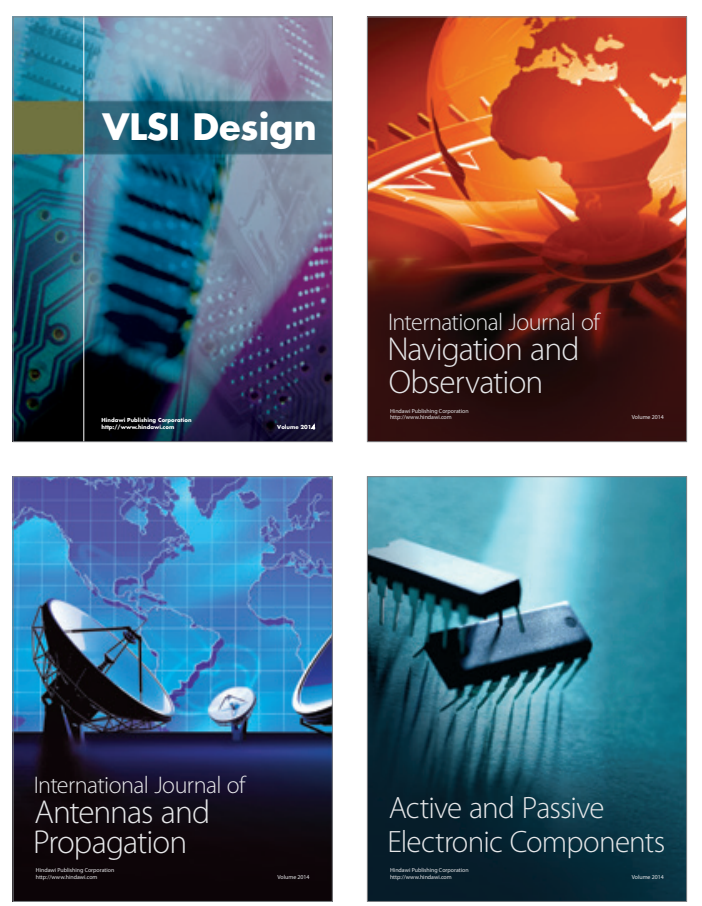
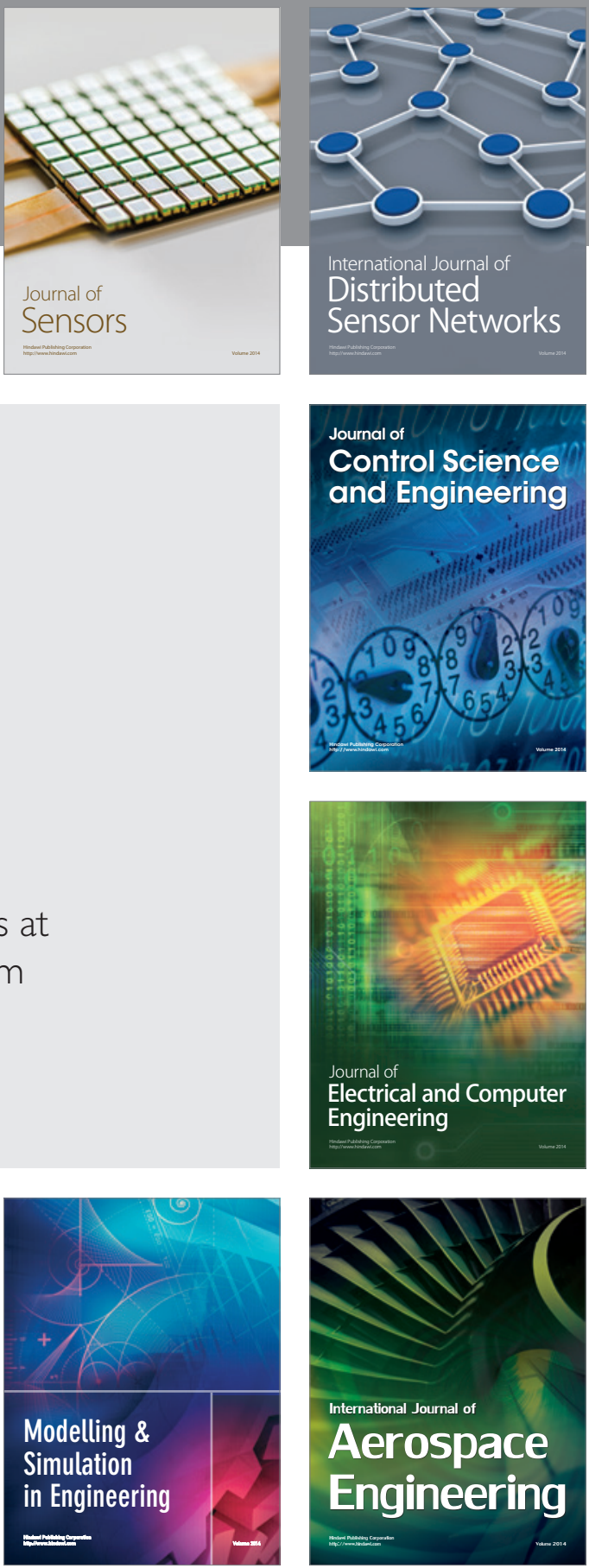

Journal of

Control Science

and Engineering
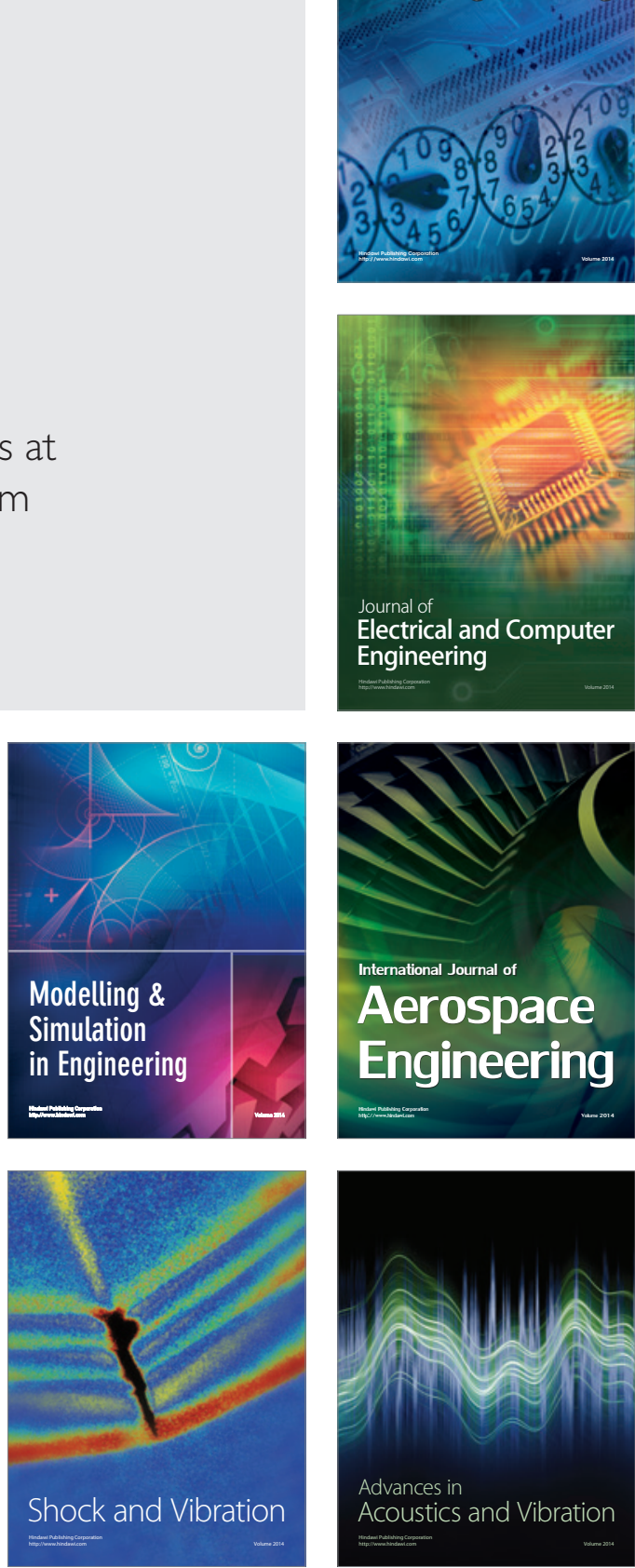